\title{
ALACAĞI DEVREDENIN BORÇLUNUN ÖDEME GÜCÜNDEN SORUMLULUĞU
}

ASSIGNOR'S LIABILITY FOR DEBTOR'S SOLVENCY

Hakemli Makale

Feride DEMIRBAŞ*

\section{IÇCiNDEKILER}

GíRiş 999

I. ALACAĞI DEVREDENIN GARANTİ SORUMLULUĞUNA GENEL BAKIŞ, BU SORUMLULUĞUN AMACI, HUKUKİ NITELIĞİ VE KARŞILAŞTIRMALI HUKUKTA

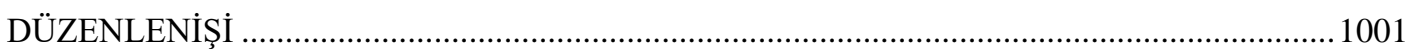

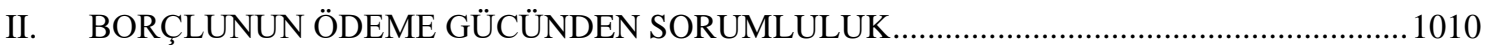

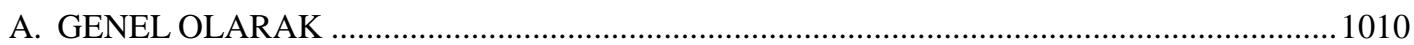

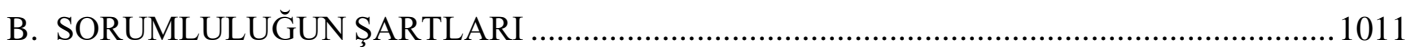

1. Edim Karşıllı̆̆ Geçerli Bir Devir İşleminin Varlı̆̆ ………………………………............1011

a. Garanti Sorumluluğunun Kural Olarak Sözleşmeden Kaynaklanan Edim Karşıllı̆ı Devirler

Bakımından Öngörülmüş Olmas1 ............................................................................................... 1011

b. Kanun veya Mahkeme Kararı Gereği Gerçekleşen Devirlerde Durum................................ 1014

2. Borçlunun Ödeme Gücünün Bulunmamas1 .......................................................................1016

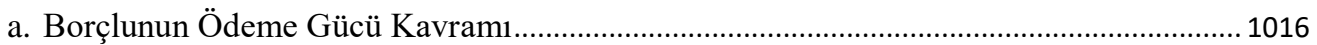

b. Devredenin Kime Karşı ve Borçlunun Hangi Andaki Ödeme Gücünden Sorumlu

Olduğunun Belirlenmesi ve İspat Sorunu.............................................................................. 1020

C. BORÇLUNUN ÖDEME GÜCÜNDEN SORUMLULUĞUN SONUÇLARI ...........................1024

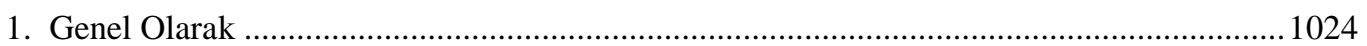

2. Sorumluluk Kapsamında Talep Edilebilecek Alacaklar......................................................1027

DOI: $10.32957 /$ hacettepehdf.943831

Makalenin Geliş Tarihi: 27.05.2021

Makalenin Kabul Tarihi: 28.10.2021

* Arş. Gör. Dr., Akdeniz Üniversitesi Hukuk Fakültesi Medeni Hukuk Anabilim Dalı. E-posta: feridedemirbas@gmail.com,

$\mathrm{Bu}$ makale konusunun araştırılması ve makalenin yazım süreçlerinde Hacettepe Hukuk Fakültesi Dergisi'nin araştırma ve yayın etiği ilkelerine uyulmuştur.

ORCID: 0000-0002-4774-343X. 
a. Devredenin kusuruna bağlı olmaksızın talep edilebilen alacaklar 1027

b. Devredenin kusuruna bağlı olarak talep edilebilen alacaklar .... 1028

III. ZAMANAŞIMI

SONUÇ 1030

KAYNAKÇA

\title{
ÖZ
}

Bu çalışmanın konusunu alacağın edim karşılığı devrinde devredenin borçlunun ödeme gücünden sorumluluğu oluşturmaktadır. Alacağı devralan borçlunun ödeme gücünün olamaması nedeniyle alacağı elde edemezse, devredenin garanti sorumluluğuna başvurabilir. Devredenin garanti sorumluluğuna ilişkin hüküm kapsam bakımından, 818 sayılı Borçlar Kanunu’nda ve 6095 sayılı Türk Borçlar Kanunu’ndan farklılık arz etmektedir. 6095 sayılı Türk Borçlar Kanunu'nun 191. maddesi ile devredenin, borçlunun ödeme gücünden sorumluluğu öngörülmüştür. Hüküm ile alacağını devreden alacaklı ile borçlu arasındaki hukuki ilişkiye yabancı olan devralanın, alacağı elde edememe rizikosuna karşı korunması amaçlanmaktadır. Alacağı devralana bu koruma sağlanırken borçlunun ödeme gücünden sorumluluğun devredenin öngörülemez biçimde aleyhine sonuçlar doğurması da engellenmeli, bunun için sorumluluğun hukuki çerçevesi dikkatle belirlenmelidir. Bu çalışmada, alacağı devredenin borçlunun ödeme gücünden sorumluluğunun hukuki niteliği, karşılaştırmalı hukukta düzenlenişi, şartları, kapsamı ve zamanaşımı konuları incelenmektedir.

Anahtar kelimeler: Alacağın devri, garanti, borçlunun ödeme gücü, borçlunun aczi, ifa güçsüzlüğü, edim karşılı̆̆ devir

\begin{abstract}
The subject of this study is the liability of the assignor for the solvency of the debtor in the assignment in exchange for a performance. If the assignee cannot obtain the claim due to the inability of the debtor to performance, assignee may resort to the warranty liability of the assignor. The provision regarding the warranty liability of the assignor differ in terms of scope in the Code of Obligations No. 818 and the Turkish Code of Obligations No. 6095. The liability of the assignor for the solvency of the debtor is regulated by the 191. article of the Turkish Code of Obligations numbered 6095. With the provisions, it is aimed to protect the assignee, who is foreign to the legal relationship between the creditor (assignor) and the debtor, against the risk of failing to obtain the claim. While providing this protection to the assignee, the assignor's liability for the debtor's solvency should be prevented from causing unpredictable consequences against the assignor, because of this inconvenience the legal framework of the liability should be carefully determined. In this study, the legal nature of the liability of the assignor to the solvency of the debtor, its regulation in comparative law, terms, content and statute of limitations are examined.
\end{abstract}


Keywords: Assigment of claim, warranty, debtor's solvency, insolvency of debtor, assignment in exchange for a performance

\section{GíRiş}

Bir malvarlığı değeri olan alacak hakkı, hak sahibi tarafından çeşitli hukuki işlemlere konu edilebilir ${ }^{1}$. Bu hukuki işlemlerden biri de alacağın devridir. Alacağın devredilmesi ile borç ilişkisinde taraf değişikliği meydana gelir, alacak hakkı devredenin malvarlığından devralanın malvarlığına geçer ${ }^{2}$. Alacağın devri ile borç ilişkisinden doğan bir talep hakkının devri gerçekleştiği için, devredenin bu borç ilişkisinden kaynaklanan yükümlülükleri devam etmektedir³ ${ }^{3}$

Alacağın devri, bir mahkeme kararına, kanun hükmüne ya da tarafların iradesine dayanabilir. Türk Borçlar Kanunu'nda alacağın devrine ilişkin hükümlerin, iradi devir esas alınarak düzenlendiği görülmektedir. Bu çalışma bakımından önem taşıyan alacağın iradi devri "alacak hakkının devreden ile devralan arasında kurulan, borçlunun rızasına gerek olmaksızın hakkın devralanın malvarlığına geçmesini sağlayan tasarruf işlemi

1 Roma hukukunda alacak hakkı ile borçlu arasında sıkı bir bağ olduğu gerekçesi ile alacağın devrinin mümkün olmadığı bilinmektedir. Ayrıntılı bilgi için bkz. VON TUHR, Andreas / ESCHER, Arnold, Allgemeiner Teil des Schweizerischen Obligationenrecht, Schluthess Verlag, Zürich, 1974, s.329; ÜÇER, Mehmet, "Roma Hukuku'nda ve Karşılaştırmalı Hukukta Alacağın Temliki”, Ankara Üniversitesi Hukuk Fakülttesi Dergisi, Y11: 2005, Cilt: 54, Sayı:3, s. 399.

2 TEKINAY, Selahattin Sulhi / AKMAN, Sermet / BURCUOĞLU, Haluk / ALTOP, Atilla, Tekinay Borçlar Hukuku Genel Hükümler, Yeniden Gözden Geçirilmiş ve Genişletilmiş Yedinci Baskı, Filiz Kitabevi, İstanbul, 1993, s. 240; WEHRLI, Thomas, Die Vertaglihe Abtretung von Forderungen, Stämfli+Cie AG, Graphisches Unternehmen, Bern 1993, s. 4; VON TUHR / ESCHER, 1974, s. 330; REETZ, Peter / BURRI, Christof, Obligationenrecht - CHK Handkommentar zum Schweizer Privatrecht Allgemeine Bestimmungen Art. 1-183 OR, Hrsg. Andreas Furrer, Anton K. Schnyder, 3. Auflage, Schulthess Juristische Medien AG, Zürich, 2016, Art. 164, N. 9; GÜNERGÖK, Özcan, Alacağın Devrinde Borçlunun Hukuksal Durumu, Vedat Kitapçılık, İstanbul, 2014, s. 8-9; TUNÇOMAĞ, Kenan, Türk Borçlar Hukuku I. Cilt Genel Hükümler, Sermet Matbaası, İstanbul, 1976, s. 1097; 23; ERCOŞKUN ŞENOL, H. Kübra, Türk Borçlar Kanunu'na Göre Alacağı Devredenin Garanti Sorumluluğu, Adalet Yayınevi, Ankara, 2021, s. 48; FRANKO, Nisim, “Alacağın Temliki”, Ankara Üniversitesi Siyasal Bilgiler Fakültesi Dergisi, Y11: 1994, Cilt: 49, Sayı: 1, s. 179.

3 VON TUHR/ESCHER, 1974, s. 343; TUNÇOMAĞ, 1976, s. 1075; GÜNERGÖK, 2014, s. 9, DAYINLARLI, Kemal, Borçlar Kanunu'na Göre Alacağın Temliki, Gözden Geçirilmiş, Güncelleştirilmiş, Genişletilmiş İkinci Baskı, Ankara, 2000, s. 57-58. 
niteliğinde bir sözleşme" olarak tanımlanabilir ${ }^{4}$. Alacağın sözleşme ile devri olarak da adlandırılan iradi devir iki aşamadan oluşmaktadır. $\mathrm{Bu}$ aşamalardan ilki borçlandırıcı işlem niteliğindeki alacağın devrine ilişkin sözleşmenin kurulması, ikincisi de tasarruf işlemi niteliğindeki alacağın devridir 5 .

İradi devir pek çok hukuki sebep (causa) ile gerçekleşebilir ${ }^{6}$. Alacak hakkı edim karşılığı (ivazlı) veya edim karşılığı olmaksızın (ivazsız), tahsil yahut teminat amacıyla devredilebilir ${ }^{7}$. Devreden, alacak hakkını devralana olan borcunu ifa yerine veya ifaya yönelik (ifa uğruna) da devredebilir, devrin çok çeşitli ekonomik sebepleri olabilir ${ }^{8}$. Bu denli çeşitli ekonomik amaçlar taşıması, alacağın devrinin uygulamadaki görünüm sahasını genişletmekte ve önemini artırmaktadır.

Alacağın devrinin hükümleri Türk Borçlar Kanunu'nun 186 vd. maddelerinde düzenlenir. Devrin; ifanın gerçekleşmesi, tarafların savunma araçları (def'i ve itirazları), öncelik hakları ve bilhassa teminatlar olmak üzere bağlı hakların geçmesi, senet ve

4 OĞUZMAN, Kemal / ÖZ, Turgut, Borçlar Hukuku Genel Hükümler Cilt-2, Gözden Geçirilmiş 14. Bası, Vedat Kitapçılık, İstanbul, 2018, s. 565; TEKİNAY/AKMAN/BURCUOĞLU/ALTOP, 1993, s. 240; GAUCH, Peter/ SCHLUEP, Walter R., Schweizerisches Obligationenrecht Allgemeiner Teil Band II, 9. Auflafe, ergänzt, verbessert und nachgeführt von Susan Emmenegger, Schluthess, ZürichBasel-Genf, 2008, N. 3407 vd., BUCHER, Eugen, Schweizerisches Obligationenrect Allgemeiner Teil onhe Deliktsrect, 2. Neuarbeitete und erweriterte Auflage, Schulthess Verlag, Zürich, 1988, s. 536; ERCOŞKUN ŞENOL, 2021, s. 48.

5 LARDELLI, Flavio, Kurzkommentar OR, Hrsg. Heinrich Honsell, Helbing Lichtenhahn Verlag, Basel, 2014, Art. 164, N. 1; TUNÇOMAĞ, 1976, s. 1090; REETZ/BURRI, 2016, Art. 164, N. 3; OZANEMRE YAYLA, Tolunay, Alacağın Devri İşleminin Geçerliliği ve Sebeple Olan İlişkisi (Illı̂liği), Turhan Kitabevi, Ankara, 2019, s. 54 vd.

6 Alacağın devri işleminin sebebe bağlı bir işlem olduğu yönünde bkz. FÄSSLER, Benedikt, "Der Factoringvertrag im Schweizerischen Recht", Zürich, 2010, N. 315-342; VON TUHR/ESCHER, 1974, s. 332; TEKINAYYAKMAN/BURCUOĞLU/ALTOP, 1993, s. 242; VARDAR HAMAMCIOĞLU, Gülşah, Medeni Hukuk'ta Tasarruf İşlemi Kavramı, On İki Levha Yayınları, İstanbul, 2014, s. 296 vd. Alacağın devrinin soyut bir işlem olduğu yönünde bkz. BUCHER, 1988, s. 539 vd. ve 554; VON TUHR/ESCHER, 1974, s. 333; REETZ/BURRI, 2016, Art. 164, N. 3; FRANKO, 1994, s. 179; Yarg. 13. Hukuk Dairesi E. 2016/13491, K. 2019/392, T. 21.1.2019, kararın tam metni için bkz. https://karararama.yargitay.gov.tr/Yargitay BilgiBankasiIstemciWeb/ (erişim tarihi: 12.5.2021)

7 Ayrıntılı açıklamalar için bkz. ENGiN, Baki İlkay, Alacağı Temlik Edenin Garanti Sorumluluğu, Seçkin Yayınları, Ankara, 2002, s. 12 vd; TUNÇOMAĞ, 1976, s. 1091; GÜNERGÖK, 2014, s. 16 vd; LARDELLI, 2014, Art.164, N. 2; GAUCH/SCHLUEP, 2008, N. 3411-3413.

8 LARDELLI, 2014, Art.164, N. 2; BUCHER, 1988, s. 538. 
belgelerin teslimi ile bilgilerin devralana verilmesi ile devredenin garanti sorumluluğuna ilişkin sonuçları bulunmaktadır.

$\mathrm{Bu}$ çalışmanın konusunu, 6098 sayılı Türk Borçlar Kanunu'nun 191 vd. maddelerinde düzenlenen alacağın sözleşme ile devrinde devredenin "garanti" sorumluluğunun kapsamında yer alan "borçlunun ödeme gücüne sahip olduğunun garanti edilmesi” oluşturmaktadır. Aynı hususun düzenlendiği 818 sayılı Borçlar Kanunu'nun 169 vd. maddelerinde Türk Borçlar Kanunu'ndan farklı bir esasın benimsenmiş olduğu görülür. İki kanunun ilgili hükümleri arasındaki temel farklılık, Türk Borçlar Kanunu'nda alacağın edim karşılığı devrinde, devredenin "garanti” sorumluluğunun kapsamının “devir sırasında alacağın varlığı”nın yanı sıra, "borçlunun ödeme gücüne sahip olduğu”nun da dahil edilmesidir. Kanunda alacağ 1 devredenin devralana karşı sorumluluğu bir "garanti” sorumluluğu olarak adlandırılmaktadır. Fakat bu ifade, sorumluluğun dayandığı esasın ve hukuki niteliğinin tam anlamıyla belirlenmesi bakımından yetersizdir. Bu nedenle öncelikle kanunda böyle bir "garanti sorumluluğu"nun niçin düzenlendiğinin ve sorumluluğun hukuki niteliğinin anlaşılması gerekmektedir. Devredene yüklenen “riziko"lardan "devir sırasında alacağın varlığından sorumluluk" ile ne kast edildiği, bu çalışmanın kapsamı dışındadır. Fakat çalışma kapsamı ile ilişkili olduğu ölçüde bu hususa da kısaca temas edilmektedir. Çalışmada esas olarak "borçlunun ödeme gücüne sahip olması" ifadesinden ne anlaşılması gerektiği, terim sorunu, böyle bir rizikonun devredene yükletilmesinin anlamı, borçlunun ödeme gücünden sorumluluğun başlangıcı, kapsamı, ispat sorunu ve sorumluluğun tabi olduğu zamanaşımı hususları incelenmektedir.

\section{ALACAĞI DEVREDENIN GARANTİ SORUMLULUĞUNA GENEL BAKIŞ, BU SORUMLULUĞUN AMACI, HUKUKİ NITELİĞİ ve KARŞILAŞTIRMALI HUKUKTA DÜZENLENIŞİ}

Alacağın devrinin hükümleri arasında TBK m. 191 vd. maddelerde düzenlenen “garanti” sorumluluğu; terminoloji, hükmün kanunun sistematiği içindeki yeri ve hukuki nitelik bakımından pek çok tartışmanın konusudur. $\mathrm{Bu}$ nedenle öncelikle hükmün düzenlenme amacının anlaşılması gerekir. Alacağı devredenin garanti sorumluluğunun 
kanunda öngörülmesinin en önemli nedeni, alacağı devralan kişinin, bu alacağı tahsil edememe rizikosuna karşı korunmak istenmesidir ${ }^{9}$. Garanti sorumluluğuna duyulan ihtiyacın temelinde, alacağın devrine ilişkin geçerli bir sözleşme ile alacağı devralanın, bu alacağı borçludan tahsil edememesi, ifa talebinin borçlu tarafından yerine getirilmemesi ihtimalinde, tahsil edemediği alacak için devredenin sorumluluğuna başvurabilmesini sağlama amacı yer almaktadır ${ }^{10}$. Alacağı devredenin devralana karşı sorumluluğunu doğuran olgu, "alacağın devrine ilişkin sözleşme” olarak adlandırılan borçlandırıcı işlemdir ${ }^{11}$. Devredenin sorumluluğuna, devralan ile arasındaki bu sözleşmeden kaynaklanan edim gereği gibi yerine getirilmediği için başvurulmaktadır.

Türk Borçlar Kanunu m. 191 uyarınca devredenin garanti sorumluluğu, alacağın iki sebepten ötürü tahsil edilememesi durumunda gündeme gelebilir. Bu sebeplerden ilki kanunda "alacağın varlığı"; öğretide ${ }^{12}$ ise "alacağın hukuki sebeplerden ötürü tahsil edilememesi” olarak ifade edilen tahsil edilememe durumudur. İkinci sebep ise kanunda "borçlunun ödeme gücüne sahip olmaması"; öğretide ${ }^{13}$ ise "alacağın fiili sebeplerle tahsil edilememesi” olarak ifade edilen tahsil edilememe durumudur. Alacağ devralan bu iki grupta toplanabilecek sebeplerden biri yüzünden, devraldığ1 alacağı borçludan tahsil edemezse, bu alacağı kendisine devredenin garanti sorumluluğuna başvurabilir.

Alacağın hukuki sebeplerle tahsil edilememesi (Richtigkeit, Verität) ifadesinden anlaşılması gereken, alacağın mevcut olmaması yahut mevcut olmakla birlikte borçlunun bazı savunmalar ileri sürerek borcu ifa etmekten kaçınması nedeniyle tahsil edilememesi

9 TUNÇOMAĞ, 1976, s. 1098; ENGİN, 2002, s. 51 vd. Yazar, bu sorumluluğun temelinde yatan düşünceyi, cismani varlığı olmayan bir malvarlığı değerini devralmak isteyenin, alacağı devredecek kişinin o alacağa ilişskin beyanlarına ve iddialarına, bir satış sözleşmesinin alıcısına nazaran daha fazla güvenmek zorunda olması olarak açıklamaktadır. Bkz. s. 56.

10 ENGIN, 2002, s. 52.

11 BUCHER, 1988, s. 574; GAUCH/SCHLUEP, 2008, N. 3502; WEHRLI, 1993, s. 18; TUNÇOMAĞ, 1976, s. 1098; OĞUZMAN/ÖZ, C. II, 2018, s. 595; ENGİN, 2002, s. 63; TEKİNAY/AKMAN/BURCUOĞLU/ALTOP, 1993, s. 241-242; LARDELLI, 2014, Art.171, N. 1; ERCOŞKUN ŞENOL, 2021, s. 240. Ayrıca alacağın devrinin tasarruf işlemi olma niteliğine ilişkin ayrıntılı açıklamalar için bkz. VARDAR HAMAMCIOĞLU, 2014, s. 71-72 ve 291 vd. Yazar, alacağın devri işleminin, alacak hakkının devreden tarafın malvarlığından devralanın malvarlığına geçmesini sağlayan bir işlem olduğunu, devir işleminin temel ilişkinden kaynaklanan borcun ifası niteliği taşıdığını belirtmektedir.

12 ENGIN, 2002, s. 52. 51.

13 ENGİN, 2002, s. 52. 
durumudur $^{14}$. Bu hallerde devralan, hukuki bazı engeller nedeniyle borçluyu ifaya zorlayamamaktadır. Devredenin alacağın mevcut olduğunu garanti etmesi, doğmuş ya da ileride doğma ihtimali bulunan bir alacağa ilişkin olabileceği gibi alacağın sona ermemiş olduğunu da kapsamaktadır ${ }^{15}$. Örneğin, alacağın dayandığı borç ilişkisinin şekle aykırılık, ehliyetsizlik, vb. gibi bir nedenle geçersiz olması durumunda devralan, borçludan tahsil edemediği alacak için devredenin sorumluluğuna başvurabilir. Borçlunun, devreden alacaklıya karşı sahip olduğu bir savunma, onun, borcu devralana ifa etmemesine imkân verebilir. Bu takdirde devralan, devredenin sorumluluğuna başvurabilir. Alacak hakkının devirden önce ifa, takas, ibra gibi bir sebeple sona ermesi veya başka bir kişiye devredilmiş olması ihtimallerinde de devredenin garanti sorumluluğu doğar ${ }^{16}$. Alacak hakkı mevcut ve geçerli olmakla birlikte devir sözleşmesi herhangi bir sebeple geçersiz ise devredenin garanti sorumluluğunun doğmadığ savunulmaktadır $^{17}$. Ayrıca, sözleşme ile devri yasaklanan bir alacağı devredenin, borçlunun devri onaylamaması halinde devralana karşı garanti sorumluluğunun devam edeceği savunulmaktadır ${ }^{18}$. Devralan, devir engelini bilmesine rağmen alacağı devralmış ve borçlu devir engelini ileri sürerek ifadan kaçınmışsa, devralanın, devredenin garanti sorumluluğuna başvuramayacağı kabul edilmektedir ${ }^{19}$.

Alacağın fiili sebeplerle elde edilememesi (Zahlungsfähigkeit, Bonität) ifadesinden anlaşılması gereken ise ifanın borçludan kaynaklanan sebeplerle gerçekleşmemesidir ${ }^{20}$. Borçlunun edimi ifa edecek gücü ya da niyeti olmadığı için borcu ifa etmemesi

14 Alacağın devir anında ya da sonraki tarihte ifa edilecekse ifa anında mevcut olması gerektiği; alacağın devir anından sonra sona ermesi durumunda bu rizikoya devralanın katlanması gerektiği hakkında bkz. TUNÇOMAĞ, 1976, s. 1099.

15 OĞUZMAN/ÖZ, C. II, 2018, s. 597.

16 ERCOŞKUN ŞENOL, 2021, s. 261.

17 OĞUZMAN/ÖZ, C. II, 2018, s. 597. Yazarlar, devredenin, devir engelini devralandan gizleyerek alacağı devretmesi durumunda genel hükümlere göre sorumlu olacağını savunmaktadır. Ayrıca bkz. ERCOŞKUN ŞENOL, 2021, s. 273 vd.

18 ERBAYRAKTAR, Burcu, Alacağın Devrinin Sözleşme ile Engellenmesi (Pactum de non cecendo), On İki Levha Yayınc1lik, İstanbul, 2021, s. 446-447.

19 ERBAYRAKTAR, 2021, s. 447.

20 ENGİN, 2002, s. 52. Devredenin borçlunun ödeme gücünden sorumluluğunun gündeme gelebilmesi için alacağın hukuki sebeplerden ötürü elde edilebilmesine bir engel bulunmamalıdır. Bkz. TUNÇOMAĞ, 1976, s. 1101; ERCOŞKUN ŞENOL, 2021, s. 293-294. 
durumunda, devralanın borçluyu ifaya zorlamasının önünde hukuki bir engel bulunmamakla birlikte, alacağı tahsil edememesi sebebiyle devredenin sorumluluğu gündeme gelebilir. Bu konu ileride ayrıntılı olarak ele alınmaktadır ${ }^{21}$.

Türk Borçlar Kanunu m. 191 vd. hükümlerinde "garanti” olarak adlandırılan sorumluluğun, müessesenin hukuki niteliği ile doğrudan ilişkili olduğu açıtır ve bu hüküm ile alacağı devralana bir teminat sağlanmak istendiği anlaşılmaktadır ${ }^{22}$. Zira bu sayede alacağı devralan, alacağın borçlusu dışında bir başka kimsenin (alacağ1 devredenin) malvarlığına başvurabilme imkânı kazanmaktadır. Alacaklının başvurabileceği alternatif bir malvarlığının sağlanması, kişisel teminatların temel amacını teşkil eder ${ }^{23}$. Alacağı devralana sağlanan bu teminatın hukuki niteliği tartışmalıdır. Öğretide teminatın hukuki niteliğinin kefalet sözleşmesi olmadığı hususunda görüş birliği bulunmaktadır ${ }^{24}$. Zira kefalet sözleşmesinden doğan borç kefilin kendi borcu olamaz; hâlbuki devreden, devir sözleşmesinden kaynaklanan kendi borcuna teminat sağlamaktadır. Ayrıca fer'i bir borç doğuran kefalet sözleşmesinden kaynaklanan kefilin sorumluluğu, asıl borcun varlığına ve geçerliliğine bağlıdır ${ }^{25}$. TBK m. 191 vd. hükümlerde ise, devredenin sorumluluğu devir sırasında alacağın mevcut olmaması rizikosunu da içerir.

Alacağı devredenin devralana karşı alacağın mevcut olmasından ve borçlunun ödeme gücünün bulunmasından sorumlu olması "garanti” olarak adlandırılsa da; öğretide bu terim eleştirilmekte, "tekeffül” veya "sağlama borcu" ifadesinin daha isabetli olduğu savunulmaktadır ${ }^{26}$. Gerek Türk gerekse İsviçre hukukunda alacağın devri işleminin

21 Bkz. III, B, 2, a.

22 TUNÇOMAĞ, 1976, s. 1098.

23 ÖZEN, Burak, 6098 Sayılı Türk Borçlar Kanunu Çerçevesinde Kefalet Sözleşmesi, Vedat Kitapçılık, İstanbul, 2017, s. 6.

24 BECKER, Herman, "Berner Kommentar, Allgemeine Bestimmungen, Art. 1-183 OR Schweizerisches Zivilgesetzbuch, Obligationenrecht", Stämpfli Verlag AG, Bern 1945, 1945, Art. 171, N. 2; VON TUHR/ESCHER, 1974, s. 332, dpn. 31a; TUNÇOMAĞ, 1976, s. 1098, DAYINLARLI, 2000, s. 210; TEKİNAY/AKMAN/BURCUOĞLU/ALTOP, 1993, s. 262; FÄSSLER, 2010, N. 262; FRANKO, 1994, s. 193.

25 ÖZEN, 2017, s. 27.

26 TUNÇOMAĞ, 1976, s. 1098; ERCOŞKUN ŞENOL, 2021, s. 243. 
dayandığı borçlandırıcı işlemden kaynaklanan bu sorumluluğun, kanunun bazı özel borç ilişkilerinde düzenlenen "tekeffül”" (kanuni garanti) sorumluluğu niteliğinde olduğu kabul edilmektedir $^{27}$. Bu görüşe göre ${ }^{28}$, devir işlemi edim karş1lığı gerçekleşmişse alacağın mevcut olmaması durumunda hakta bir eksikliğe (zapttan sorumluluğa benzer bir duruma); borçlunun ödeme gücünün bulunmaması nedeniyle tahsil edilememesinde satılanın ayıplı olmasına (özellikle zikir ve vaat edilen özelliklerin bulunmamasına) ${ }^{29}$ benzer bir durumun söz konusu olduğu kabul edilmektedir ${ }^{30}$. Alacak hakkını bir anlamda satan durumundaki devredenin -devralana bu hakkı satmış fakat kazandıramamış olduğu için- kusuru olmasa bile devralanın ifaya olan menfaatini parasal olarak karşılamakla yükümlü tutulduğu ileri sürülmektedir ${ }^{31}$. Mehaz İsviçre Borçlar Kanunu'nun TBK m. 191 hükmüne karşılık gelen Art. 171 hükmünün başlı̆ğ "Gewährleistung” olup bu kavram “tekeffül” olarak Türkçe'ye çevrilebilir. Nitekim bu kavrama aynı kanunun satıcının ayıptan doğan sorumluluğunu düzenleyen Art. 197 hükmünde de rastlanmaktadır. O halde devredenin "garanti sorumluluğu"nun hukuki niteliğinin belirlenmesine ilişkin tartışmanın temelinde, ayıptan doğan sorumluluğun hukuki niteliğine ilişkin tartışmalar yer almaktadır. Öğretide bu sorumluluğu açıklayan iki teori tekeffül teorisi ve ifa teorisidir $^{32}$. Tekeffül teorisine göre ayıplı ifada bulunan, bir sözleşme hükmüne aykırı davranmış olmaz; bu sorumluluğun dayanağı kanun hükmüdür ${ }^{33}$. İfa teorisini savunan yazarlara göre ise ayıptan doğan sorumluluk, borçlunun edim yükümlülüğünün kapsamındadır; ayıplı ifa sözleşmenin müspet ihlali niteliği taşı ${ }^{34}$. Bu sorumluluk özel

27 TUNÇOMAĞ, 1976, s. 1098; BECKER, 1945, Art. 171, s. 802.

28 TUNÇOMAĞ, 1976, s.1098; ENGİN, 2002, s. 68.

29 FRANKO, 1994, s. 191. Öğretide Engin, bu durumda borçlunun ödeme gücünden sorumluluğun maddi bir ayıp sayılamayacağını, dolayısıyla devredenin sorumluluğu ile satıcının sorumluluğu arasında sadece bir benzerlik olduğunu belirtmektedir. Bkz. ENGİN, 2002, s. 68.

30 SEROZAN, Rona, Borçlar Hukuku Özel Bölüm, 2. Baskı, Filiz Kitabevi, İstanbul, 2006, s. 129. Yazar, bu durumu ekonomik ayıbın tipik örneği olarak nitelendirmektedir.

31 SEROZAN, 2006, s. 129.

32 Konuyla ilgili ayrıntılı açıklamalar için bkz. SEROZAN, 2006, s. 129; KAHVECİ, Nalan, "Taşınır Satımında Ayıplı Mal Nedeniyle Tüketicinin Sözleşmeden Dönmesi”, Adalet Yayınevi, Ankara, 2014, s. 36 vd.

33 BECKER, 1945, Art. 171, N. 1.

34 ARAL, Fahrettin, Kötü İfa, Yetkin Yayınları, Ankara, 2011, s. 115; KAHVECİ, 2014, s. 37; SEROZAN, 2006, s. 132-133. 
bir garanti sorumluluğu biçiminde düzenlenmiş olsa da, temelinde sözleşmeye aykırılığgn bulunduğu kabul edilmektedir ${ }^{35}$. Alacağı devralan, alacağın mevcut olmaması ya da borçlunun ödeme gücünün bulunmaması nedeniyle borca aykırılığa ilişkin genel hükümlere (TBK m. 112 vd.) başvurabileceği gibi, "garanti” sorumluluğunu düzenleyen TBK m. 191 vd. hükümlere de başvurabilir ${ }^{36}$.

Alacağın edim karşılığı olmaksızın devrinde devrin dayandığı temel ilişki bağışlama sözleşmesidir. Bu nedenle devredenin garanti sorumluluğunun genel hükümler arasında değil, devrin dayandığı hukuki sebebe göre özel hükümler arasında düzenlenmesinin daha isabetli olacağı savunulmaktadır ${ }^{37}$. Bununla birlikte Türk Borçlar Kanunu'nun özel hükümleri arasında düzenlenen tekeffül hükümlerine nazaran devredenin garanti sorumluluğuna ilişkin hükümlerin özel hüküm niteliği taşıdığ1; ancak garanti sorumluluğuna ilişkin hükümlerde boşlukların doldurulması bakımından tekeffül hükümlerine başvurulabileceği kabul edilmektedir ${ }^{38}$.

Öğretide savunulan ve bizim de katıldı̆̆ımız görüşe göre, TBK m. 191 vd. hükümlerde öngörülen "garanti” sorumluluğu, edim karşılığı devirlerde devredene kanundan kaynaklanan bir teminat yükümlülüğü getirmektedir ${ }^{39}$. Bu yükümlülük bağımsız (müstakil, fer’i olmayan) bir sözleşme ya da garanti taahhüdü olarak nitelendirilmemelidir; zira bu taahhüdün alacağın devri sözleşmesinden ayrı bir varlığı bulunmamaktadır. Fakat taraflar arasında ayrıca ve açıkça kanunda öngörülenden daha geniş bir riziko üstlenilmemişse, TBK m. 191 vd. hükümleri ile, kaynağını kanundan alan, bağımsız garanti sözleşmesi niteliği taşımayan bir teminatın öngörüldüğü kabul

35 SEROZAN, 2006, s. 132.

36 HATEMI, Hüseyin / GÖKYAYLA, Emre, Borçlar Hukuku Genel Hükümler Genel Bölüm, 3. Bası, Vedat Kitapçılık, İstanbul, 2015, s. 382; SEROZAN, 2006, s. 129.

37 ÜÇER, 2005, s. 427; TUNÇOMAĞ, 1976, s. 1098. Yazar sadece satıcının ayıptan doğan sorumluluğuna ilişkin hükümlere başvurulmasının edim karşılığı olmayan devrilerde uygulanmaması gerektiği için müessesenin genel hükümler arasında düzenlenmesi gerektiğini belirtmektedir. İsviçre hukukunda aynı yönde bkz. GAUCH/SCHLUEP, 2008, N. 3502.

38 GÜNERGÖK, 2014, s. 113; ENGİN, 2002, s. 66-67.Örneğin alacağ1 devredenin garanti sorumluluğuna başvurabilmek için devralanın yerine getirmesi gereken gözden geçirme ve bildirim külfetleri bulunmamaktadır. İsviçre hukukunda aynı yönde bkz. WEHRLI, 1993, s. 18.

39 REISOĞLU, Seza, Garanti Mukavelesi, Ajans-Türk Matbaası, Ankara, 1963, s. 54, dpn. 2. 
edilmektedir ${ }^{40}$. Bununla birlikte kanunda öngörülenden daha fazla rizikonun devreden tarafından üstlenilmesi halinde bu taahhütlerin hukuki niteliği tartışmalıdır. Öğretide bu hallerde bağımsız bir garanti sözleşmesinin bulunduğu ileri sürülmektedir ${ }^{41}$. Örneğin borçlunun, borcun muaccel olmasından sonra ödeme gücünü kaybetmesinden sorumlu olunduğunun ya da edim karşılığı olmayan devirlerde borcun varlığının ve borçlunun ödeme gücünün bulunduğunun taahhüt edilmesinde durum böyledir. Alacağın devredilmesiyle TBK m. 189/I uyarınca devralana geçen, devredenin kişiliğine bağlı olmayan öncelik hakları ile bağlı hakların varlığının ve teminat veren borçluların ödeme güçlerinin garanti edilmesi de sık rastlanan örneklerdendir. Benzer şekilde devredenin, borçlunun ifa gücü olmasına rağmen ifa niyetinin olmaması nedeniyle borcunu yerine getirmekten kaçınması rizikosunu üstlenmesi durumunda kanunda öngörülenden daha geniş ve bir sorumluluk üstlenilmiş demektir ${ }^{42}$. Öğretide savunulan diğer görüşe göre ise taahhüdün bağımsız ya da bağımsız olmayan garanti sözleşmesi niteliğinde mi olduğu, üstlenilen rizikonun niteliğine göre belirlenmelidir ${ }^{43}$.

Alacağı devredenin, alacağın tahsil edilememesinde kusuru bulunuyorsa, devredenin, borcu kusurlu olarak ihlal etmesi sebebiyle (TBK m. 112 vd.) sorumluluğuna başvurulmasına hukuki bir engel yoktur ${ }^{44}$. Bununla birlikte, devredenin TBK m. 191 vd. hükümleri uyarınca alacağın tahsil edilememesi nedeniyle doğan sorumluluğu, kusura dayanan bir sorumluluk değildir ${ }^{45}$. Örneğin devredenin borçlunun ödeme gücünün

$40 \mathrm{Bu}$ teminatın niteliğinin bağlı (bağımsız olmayan) bir garanti sözleşmesi olduğu yönünde bkz. TANDOĞAN, Haluk, Borçlar Hukuku Özel Borç İlişkileri C.II, Beşinci Tıpkıbasım, Vedat Kitapçl1ı, İstanbul, 2010, $\quad$ s. $\quad 835 ; \quad$ ENGIN $\quad 2002, \quad$ s. $130-131$; TEKINAY/AKMAN/BURCUOĞLU/ALTOP, 1993, s. 262.

41 REİSOĞLU, 1963, s. 54; TANDOĞAN, 2010, s. 833; ÜÇER, 2005, s. 428. İsviçre hukukunda devredenin borçlunun ödeme gücüne ilişkin garanti sorumluluğu kanundan kaynaklanmadığı, ancak sözleşme ile üstlenilebildiği için bu taahhüdün hukuki niteliği bağımsız garanti sözleşmesi olarak kabul edilmektedir. Bkz. LARDELLI, 2014, Art.171, N. 8; aynı yönde bkz. BGE 61 II 102/104 E. 1, BGE 53 II 111/116, ilgili kararlar için bkz. KRAUSKOPF, Frédéric, Präjudizienbuch OR, Die Rechtsprechung des Bundesgerichts (1875-2015), Hrsg. Peter Gauch / Viktor Aepli / Hubert Stöckli, 9. Aufl., Zürich- Basel - Genf, 2016, Art. 171, N. 6.

$42 \mathrm{Bu}$ durumda bağımsız olmayan bir garanti sözleşmesinin var olduğu hususunda bkz. ERCOŞKUN ŞENOL, 2021, s. 337.

43 ERCOŞKUN ŞENOL, 2021, s. 336-337.

44 TEKINAY/AKMAN/BURCUOĞLU/ALTOP, 1993, s. 261; ENGIN, 2002, s. 53.

45 OĞUZMAN/ÖZ, C. II, 2018, s. 599; ENGİN, 2002, s. 55 ve 69; ERCOŞKUN ŞENOL, 2021, s. 244. 
varlığına ilişkin haklı görülebilecek bilgisizliği, onun garanti sorumluluğunu ortadan kaldırmaz. Bu nedenle TBK m. 191 vd. hükümleri, devralan bakımından daha elverişlidir.

Türk hukukunda alacağı devredenin garanti sorumluluğunun düzenlendiği Türk Borçlar Kanunu hükümleri emredici nitelik taşımamaktadır. Bu sorumluluğun sözleşme ile tamamen ortadan kaldırılabilmesi veya kapsamının değiştirilmesi (genişletilmesi veya daraltılmas1) mümkündür ${ }^{46}$.

Alacağın devrinde devredenin garanti sorumluluğu İsviçre, Alman ve Avusturya hukuk sistemlerinde de öngörülmüştür. Bu hukuk sistemlerinde alacağı devredenin garanti sorumluluğuna ilişkin hükümlerin temel olarak iki bakımdan farklılaştığı görülmektedir. Farklılıklardan ilki, sorumluluğun ilgili kanunlarda düzenlendiği yer bakımından; ikincisi de sorumluluğun kapsamı bakımındandır.

İsviçre hukukunda devredenin garanti sorumluluğu, mehaz kanunun (OR) Art. 171 vd. hükümlerde düzenlenmektedir. $\mathrm{Bu}$ hükümler sistematik açıdan, tıpkı Türk hukukundaki gibi, genel hükümler arasında yer alan alacağın devrine ilişkin hükümlerdir ${ }^{47}$. Bahsi geçen hükümler uyarınca, edim karşılığı devirde devredenin kanundan kaynaklanan garanti sorumluluğu, kural olarak sadece alacağın, devri sırasında mevcut olduğuna (varlığına) ilişkindir (Bestand der Forderung, Verität). Devredenin, borçlunun ödeme gücünden (Zahlungsfähigkeit des Schuldners, Bonität) sorumlu olması için, bunu açıkça üstlenmiş olması gerekir ${ }^{48}$. Edim karşılığı olmayan devride devreden sadece alacağın varlığından sorumludur.

Avusturya hukukunda alacağı devredenin garanti sorumluluğu, ABGB Art. 1397 vd. hükümlerde düzenlenmiştir. Avusturya Medeni Kanunu’nun sistematiği, Türk-İsviçre

46 WEHRLI, 1993, s. 18-19; REETZ/BURRI, 2016, Art. 171, N. 1; BECKER, 1945, Art. 171, N. 4; LARDELLI, 2014, Art.171, N. 656; OĞUZMAN/ÖZ, C. II, 2018, s. 597, dpn. 124; ENGİN, 2002, s. 69; ERCOŞKUN ŞENOL, 2021, s. 245.

47 LARDELLI, 2014, Art.171, N. 1 vd; BECKER, 1945, Art. 171, N. 1 vd. İsviçre Borçlar Kanunu'nda devredenin garanti sorumluluğunun sistematik açıdan genel hükümler arasında düzenlenmiş olmasının tarihsel sebebinin, alacağın devrinin sadece bir borçlandırıcı işlem olarak değerlendirilmesi olduğu; Fransız ve Avusturya Medeni Kanunlarındaki benzer yaklaşım hakkında açıklamalar ve tarihçe için bkz. ENGIN, 2002, s. 58.

48 WEHRLI, 1993, s. 23; LARDELLI, 2014, Art.171, N. 6 vd; BECKER, 1945, Art. 171, N. 11; REETZ/BURRI, 2016, Art. 171, N. 1 vd. 
kanunlarının sistematiğinden oldukça farklı olmakla birlikte bu kanunda da alacağın devri, borç ilişkilerinin genel hükümleri arasında düzenlenmiştir. Bu hukuk sisteminde alacak, edim karşılığı devredilmişse devreden, devralana karşı hem alacağın varlığından hem de borçlunun ödeme gücünden sorumludur ${ }^{49}$. Alacak edim karşıllı̆̆ devredilmemişse, devredenin garanti sorumluluğu bulunmamaktadır.

Alman hukukunda, alacağı devredenin garanti sorumluluğu, sistematik açıdan oldukça farklı biçimde düzenlenmiştir. Alman Medeni Kanunu'nun (BGB) §-398-§413 arasında düzenlenen alacağın devri hükümleri arasında devredenin garanti sorumluluğuna yer verilmemiştir. $\mathrm{Bu}$ hukuk sisteminde alacağın edim karşılığ 1 devri hak satış1 (Rechtskauf) olarak değerlendirilmektedir (BGB §-453) ${ }^{50}$. Satıcının, (devredenin) alacak hakkını, alıcıya (devralana) her türlü ayıptan arınmış olarak devretme yükümlülüğü bulunmaktadır (BGB §-453/I ve §-433/I). Bunun bir sonucu olarak, devredenin, satıcının ayıptan doğan sorumluluğuna ilişkin hükümler uyarınca (§-437 vd.) sorumluluğu bulunup, sadece devredenin açıkça üstlenmesi durumunda alacağın varlığından ve borçlunun ödeme gücünden dolayı bir "garanti" sorumluluğunun olacağı kabul edilmektedir $^{51}$. Bir diğer ifadeyle, devredilen alacağın mevcut olmaması garanti sorumluluğu kapsamında değil, borca aykırılığa ilişkin genel hükümlerin kapsamında değerlendirilmektedir ${ }^{52}$. Ayıptan doğan sorumluluk bağlamında, borçlunun ödeme gücünün alacağın taşıması gereken bir özelliği olmadı̆̆ı gerekçesiyle satıcının (devredenin) borçlunun ödeme gücünden sorumluluğu kabul edilmemektedir ${ }^{53}$. BGB §365 hükmünde yapılan yollama nedeniyle alacağın ifa yerine devredilmesi halinde de satıcının ayıptan doğan sorumluluğuna ilişkin §-437 vd. hükümlerin uygulanacağı açıkça öngörülmüştür. Devrin edim karşılığı gerçekleşmemesi durumunda ise bağışlama

49 NEUMAYR, Mathias, Kurzkommentar Zum ABGB, Hrsg. Helmut Koizol/Raimund Bydlinski/ Raimund Bollenberger, 2. überarbeitete und erweiterte Auflage, Springer Wien-New York, 2007, s. 1641, n. 1-2; ENGIN, 2002, s. 59.

50 FAUST, Florian, BeckOK BGB, Herausgegeben von Wolfgang Hau, Roman Poseck, 57. Edition, C.H. Beck, München, 2021, § 453, N. 20, https://beck-online.beck.de , (erişim tarihi: 26.5.2021).

51 FAUST, 2021, § 453, N. 16-20; ENGİN, 2002, s. 61 ve ayrıntılı açıklamalar için s.165 vd.

52 FAUST, 2021, § 453, N. 16.

53 FAUST, 2021, § 453, N. 20 ŞENOL, 2021, s. 223, dpn. 818'deki yazarlar. 
sözleşmesinde hukuki ayıptan sorumluluğa ilişkin BGB §-523 hükmü uygulama alanı bulur.

\section{BORÇLUNUN ÖDEME GÜCÜNDEN SORUMLULUK}

\section{A. GENEL OLARAK}

Türk Borçlar Kanunu m. 191 hükmü uyarınca alacağı edim karşılığında devredenin garanti sorumluluğunun kapsamı, bu hükme karşılık gelen 818 sayılı Borçlar Kanunu'nun 169. maddesinden daha geniş bir sorumluluk olarak belirlenmiştir. Bu değişiklik alacağ edim karşılığında devredenin garanti sorumluluğunun kapsamına "borçlunun ödeme gücü"nden sorumluluğun dahil edilmesidir. "Borçlunun ödeme gücü" kavramının anlaş1labilmesi, bu kavram ile ifade edilmek istenen hususun ne olduğu, hangi borçlunun hangi andaki ödeme gücünün kastedildiği gibi pek çok hususun açıklanmasını gerektirmektedir. Mehaz İsviçre Borçlar Kanunu'nda konuya ilişkin düzenlemelerin 818 sayılı Borçlar Kanunu ile paralel olduğu belirtilmişti. Acaba Türk kanun koyucusu, hangi saik ile mehaz kanunda ve önceki kanunumuzda öngörülen sorumluluk kapsamını genişletmiş olabilir? Hükmün gerekçesinde bu saikin ne olduğuna ilişkin bir açıklama yer almamaktadır. Devredenin, borçlunun ödeme gücünün bulunmadığını bile bile bu alacağı devretmesi durumunda devralanın, devredenin kusur sorumluluğuna başvurabilmesine hiçbir hukuki engel yokken, kanunda niçin devredene hukuki ilişkideki menfaatler dengesini bozabilecek biçimde bir kusursuz sorumluluğun yüklendiği anlaşılamamaktadır ${ }^{54}$. Fakat doğurduğu sonuçlar bakımından alacağı devralanın korunmasına hizmet ettiği anlaşılan bu hükmün, alacağı devredenin öngörülemez biçimde aleyhine yorumlanmaması son derece önemlidir. Özellikle "Borçlunun "ödeme gücü bulunmasına rağmen ödeme konusunda isteksiz davranması, bir 'ifa güçsüzlüğü' olmamasına rağmen borçlunun borcunu ifa etmemesi halinde acaba devralan kolaylıkla devredenin garanti sorumluluğuna başvurabilmeli midir?”, ya da “Devir işlemi ile birlikte devralana geçen teminatlara henüz başvurulmadan devredenin sorumluluğuna başvurulabilmeli midir?" gibi pek çok soruya cevap verilmesi gerekmektedir. Bu nedenle

54 Bu değişikliğin isabetsiz olduğu yönünde bkz. ENGİN, Baki İlkay, "Alacağın Temliki ve Borcun Nakli”, Türk Borçlar Kanunu Sempozyumu, On İki Levha Yayınları, İstanbul, 2012, s. 162. 
alacağı devredenin borçlunun ödeme gücünden sorumluluğunun şartları, kapsamı ve ispat sorunu değerlendirilmelidir.

\section{B. SORUMLULUĞUN ŞARTLARI}

\section{Edim Karşılığı Geçerli Bir Devir İşleminin Varlığı}

\section{a. Garanti Sorumluluğunun Kural Olarak Sözleşmeden Kaynaklanan Edim} Karşılığı Devirler Bakımından Öngörülmüş Olması

Türk Borçlar Kanunu'nun 191 vd. hükümleri uyarınca alacağı devredenin borçlunun ödeme gücünden sorumluluğunun doğması için esas olarak devrin bir edim karşılığında gerçekleşmesi gerekir. Alacağın kanun gereği ya da edim karşılığı olmaksızın devrinde, devredenin, borçlunun ödeme gücünden sorumluluğu bulunmamaktadır ${ }^{55}$. Devrin edim karşılığ gerçekleşmiş sayılması için hukuki sebebi oluşturan devir sözleşmesinde bir karşılık (ivaz) belirlenmesi gerekir. Bu karşıllk para olabileceği gibi başka bir şey verme, yapma veya yapmama edimi, bir başka alacak olabilir $^{56}$.

Alacağ1 devredenin, borçlunun ödeme gücünden sorumlu olabilmesi için, devir sözleşmesinin geçerli şekilde yapılması gerekir. Bu şekil TBK m. 184 hükmü uyarınca yazılı şekildir. Devir işlemi şekle aykırılık nedeniyle geçersiz ise, devredenin borçlunun ödeme gücünden sorumluluğu da gündeme gelmez. Karşı edim sözlü olarak kararlaştırılmışsa ve devir sözleşmesinde yer almıyorsa, devrin edim karşılığı gerçekleştiğinin, bunu iddia eden tarafından senetle ispata ilişkin kurallar çerçevesinde ispatlanması gerekmektedir ${ }^{57}$.

Devredenin garanti sorumluluğunun bir diğer şartı da, alacağın devredilebilir nitelik taşımasıdır. Kanundan, sözleşmeden ya da işin niteliğinden kaynaklanan bir devir

55 Bu konu hakkında ayrıntılı açıklamalar için bkz. III, B, 2, a, b

56 ERCOŞKUN ŞENOL, 2021, s. 255; GÜNERGÖK, 2014, s. 120.

57 GÜNERGÖK, 2014, s. 121, dpn. 635. 
yasağının bulunmasına rağmen alacak devredilmişse, devredenin TBK m. 191/I hükmü uyarınca garanti sorumluluğu gündeme gelmez ${ }^{58}$.

Kanunda "devir sırasında alacağın var olmaması" devredenin garanti sorumluluğunu doğuran bir riziko olduğu için, devredilen alacağın devir sırasında sona ermiş ya da herhangi bir sebeple geçersiz olması durumunda devredenin borçlunun ödeme gücünün bulunmaması nedeniyle değil, bu sebeple garanti sorumluluğu gündeme gelebilir $^{59}$. Esasında TBK m. 191 hükmünde devredenin sorumlu olduğu haller, bütün ifa engellerini içine alacak biçimde kaleme alınmıştır. Öyle ki devreden ile borçlu arasındaki hukuki ilişkide edimin başlangıçtaki objektif imkansızlığı dahi, devredenin garanti sorumluluğunun kapsamındadır ${ }^{60}$. Bununla birlikte, TBK m. 191 uyarınca sorumluluk sadece "alacağın varlığına" ve "borçlunun ödeme gücüne" ilişkin olduğu için, devir sözleşmesinin hukuka ve ahlaka aykırılık, ehliyetsizlik, irade bozukluğu halleri nedeniyle iptal hakkı kullanıldığı için geçersiz olması durumunda artık devredenin garanti sorumluluğunun bulunmadığına değinilmişti ${ }^{61}$.

Alacaklının alacağını devralana olan borcunu ifa etmek için devrettiği ifaya yönelik (ifa uğruna) devirlerde (TBK m. 192) devredenin garanti sorumluluğunun bulunup bulunmadığ1 değerlendirilmelidir. Öğretide, devredilen alacak mevcut değilse ya da borçlunun ödeme gücü bulunmadığından dolayı tahsil edilememişse, alacağı devretmiş olan borçlunun borcunun mahsup edilemeyeceği, borcun varlığını sürdüreceği ve bu durumun alacağı devredenin garanti sorumluluğunun yerine geçeceği ileri sürülmektedir ${ }^{62}$. Devralan "borçludan aldığı veya gereken özeni gösterseydi alabilecek olduğu" miktarı kendi alacağına mahsup edebilir. Alacağın bir kısmı tahsil edilmişse, bu miktar, devredenin devralana olan borcuna mahsup edilir. Öğretide alacağın edim karş1lığında ifaya yönelik devredildiği hallerde, borçlunun ödeme gücünün bulunmaması

58 OĞUZMAN/ÖZ, C. II, 2018, s. 597; ERCOŞKUN ŞENOL, 2021, s. 2265-266. Yazar devretmeme anlaşmasının alacağın devrinin geçerliliğini etkilememesi gerektiği görüşünün son yıllarda ağırlık kazanmaya başladığını belirtmektedir.

59 OĞUZMAN/ÖZ, C. II, 2018, s. 597.

60 LARDELLI, 2014, Art.171, N. 3; SEROZAN, 2006, s. 129.

61 Bkz. II.

62 OĞUZMAN/ÖZ, C. II, 2018, s. 601. 
halinde devredenin garanti sorumluluğuna başvurulmaktansa, devredenin, borca aykırılık nedeniyle sorumluluğuna başvurulmasının (devredene karşı eski alacağını ileri sürmesinin) daha sade ve pratik bir çözüm olduğu ileri sürülmektedir ${ }^{63}$. TBK m. 192 hükmünün, kanunun sistematiği içinde yanlış yerde bulunduğu, hükmün, devredenin garanti sorumluluğu ile ilgili bir hüküm olmadığı, alacağını ifaya yönelik devredenin sorumluluğu devam ettiği için ayrıca bir de garanti sorumluluğunun kabul edilmesinin anlamlı olmadığı isabetli olarak savunulmaktadır ${ }^{64}$. Gerçekten de, devralan, borçlunun ödeme gücü bulunmadığg için alacağı elde edemezse, alacağını devreden borçlunun borcuna mahsup edilecek bir tahsilat bulunmayacağı için, devralanın, borçlunun borcunu ifa etmemesinden kaynaklanan sorumluluğuna başvurması olağandır. Çünkü ifaya yönelik devride devredenin borcu devir anında değil, devralan bu alacağı tahsil ettiğinde sona erer ${ }^{65}$. Dolayısıyla borçlunun “devreden" sıfatıyla garanti sorumluluğuna başvurulmasına ihtiyaç bulunmamaktadır ${ }^{66}$.

İfa yerine alacağın devrinde de benzer bir sonuca ulaşılmaktadır. Sözleşmede açıkça kararlaştırılmadığı müddetçe devrin, ifaya yönelik devir olduğu kabul edilmektedir $^{67}$. Şüphe halinde devrin ifa yerine gerçekleştiği kabul edilecek olursa, devirle birlikte devredenin borcu sona ereceği için, devralanın alacağı tahsil edip edememiş olması önem arz etmeyecektir. Alacağın ifa yerine devredildiği hallerde artık, devralanın borçlunun borcunu ifa etmemesinin rizikosunu sözleşme ile üstlendiğinin kabul edilmesi gerektiği savunulmaktadır ${ }^{68}$.

Alacak, bir edim karşılığı olmaksızın devredilmişse kanun gereğince devredenin borçlunun ödeme gücünden sorumluluğu bulunmamaktadır. Bununla birlikte, devredenin garanti sorumluluğuna ilişkin hükümlerin emredici nitelik taşımaması nedeniyle,

63 ENGIN, 2002, s. 155-156. Bu durumda alacaklının devredenin garanti sorumluluğuna da başvurabileceği yönünde bkz. REETZ/BURRI, 2016, Art. 171, N. 6.

64 OĞUZMAN/ÖZ, C. II, 2018, s. 601; ENGIN, 2002, s. 157.

65 OĞUZMAN/ÖZ, C. II, 2018, s. 602.

66 AKSOY, 2021, s. 156.

67 AKSOY, 2021, s. 155.

68 TEKINAY/AKMAN/BURCUOĞLU/ALTOP, 1993, s. 261; OĞUZMAN/ÖZ, C. II, 2018, s. 602; AKSOY, 2021, s. 155, GÜNERGÖK, 2014, s. 130-131. 
devredenin, edim karşılığı olmayan devrilerde borçlunun ödeme gücünü ayrıca garanti etmesi mümkündür. Devredenin böyle bir taahhütte bulunmasına hukuki bir engel bulunmamaktadır. Kanunda edim karşılı̆̆ olmayan devrilerde devredenin garanti sorumluluğunun öngörülmemiş olmasının nedeninin hakkaniyet düşüncesi olduğu ileri sürülmektedir ${ }^{69}$.

Alacağın edim karşılığı devrinde devredenin borçlunun ödeme gücünden sorumlu olabilmesi için, bu sorumluluğun sözleşme ile ortadan kaldırılmamış olması gerekir. Devredenin, borçlunun ödeme gücünden sorumluluğu süre bakımından da sınırlandırılabilir. Örneğin devredenin alacağın tahsil edilemeyeceğinin anlaşılmasından itibaren belli bir süreyle sorumlu olacağı kararlaştırılabilir. Benzer biçimde, sözleşmede, sorumlu olunan meblağa bir üst sınır belirlenmesi, sorumluluğun geciktirici ya da bozucu koşula bağlanması mümkündür. Bu hallerde sürenin geçmesi, üst sınırın aşılması, koşulun gerçekleşmesi ya da gerçekleşmemesi vb. göre devredenin borçlunun ödeme gücünden sorumluluğu tayin edilecektir.

\section{b. Kanun veya Mahkeme Kararı Gereği Gerçekleşen Devirlerde Durum}

Alacağı devredenin, borçlunun ödeme gücünden sorumlu olması için, devrin kural olarak kanun gereği gerçekleşmiş bir devir olmaması gerekir. Bir kanun hükmü sebebiyle alacağın devredildiği hallerde devredenin herhangi bir garanti sorumluluğu bulunmamaktadır (TBK m. 191/II). Bu genel kuralın istisnası niteliğindeki düzenlemeye, mirasın paylaşılmasının tamamlanması ve sonucuna ilişkin hükümlerden olan TMK m. 679 hükmünde rastlanmaktadır. Bu hüküm uyarınca "Mirasçılar, paylaşmada her birine özgülenmiş olan alacakların varlığını birbirlerine karşı garanti ettikleri gibi; borsaya kayıtlı olan klymetli evrak dışında, alacağın mirasçının hakkına mahsup edilen miktarı için borçlunun ödeme gücünden adî kefil gibi sorumludurlar.”. Bu hüküm ile kanun gereği (miras yoluyla) devralınan bir alacaktan ötürü, bu alacağı devralana karşı diğer mirasçıların alacağın varlığına ilişkin bir garanti sorumluluklarının bulunduğu hükme bağlanmıştır. Bununla birlikte, borçlunun ödeme gücünden sorumluluk bakımından adi kefalete ilişkin hükümlere yollama yapılmasının çelişkili bir durum yarattığı ileri

69 GÜNERGÖK, 2014, s. 119. 
sürülmektedir ${ }^{70}$. Bu çelişkinin sebebi olarak ise, Türk Medeni Kanunu'nun yürürlüğe girdiği dönemde 818 sayılı Borçlar Kanunu'nun yürürlükte olması ve bu kanunda da devredenin borçlunun ödeme gücünden sorumluluğunun öngörülmemiş olmas1 gösterilmektedir ${ }^{71}$. Dolayısıyla adi kefalete ilişkin hükümlere atıf yapılmasının bir zaruret olarak ortaya çıktığ 1 sonucuna ulaşılmaktadır.

Türk Borçlar Kanunu'nda alacağın bir mahkeme kararı ile bir kişiye intikal etmesinde devredenin, borçlunun ödeme gücünden sorumlu olup olmadığı hususu açık değildir. Böyle bir durumda devir devredenin iradesinden kaynaklanmadığı için, devredenin borçlunun ödeme gücünden sorumluluğunun da söz konusu olmayacağı, ileri sürülen görüşlerden biridir ${ }^{72}$. Bununla birlikte, alacağın mahkeme kararı ile devrinde iradi devirde yapılan değerlendirmeden farklı bir değerlendirme yapılmaması; devir borçlusunun devirden kaçınması sebebiyle dava açılmış olacağı için devredenin sorumluğunun da farklılık göstermemesi gerektiği savunulmaktadır ${ }^{73}$. Kanaatimizce de ikinci görüşe üstünlük tanımak ve edim karş1lığı gerçekleşen bir devir işleminin devredenin devirden kaçınması sebebiyle mahkeme kararı neticesinde devralınması durumunda da devredenin borçlunun ödeme gücünden sorumluluğunun var olduğunu kabul etmek daha isabetlidir ${ }^{74}$. Zira bu sorumluluk, kaynağını alacağın devrine ilişkin borçlandırıcı işlemden almaktadır. Dolayısıyla devreden devir işlemini gerçekleştirmekten kaçındığı için uyuşmazlık mahkemeye intikal ettiğinde de borçlunun ödeme gücünden sorumluluğu söz konusu olmalıdır. Aksi yöndeki bir yorum, bu sorumluluktan kurtulmak isteyen devir taahhüdünde bulunanları, ifadan haklı bir neden olmaksızın kaçınmaya teşvik edecektir.

70 ERCOŞKUN ŞENOL, 2021, s. 297-298.

71 ERCOŞKUN ŞENOL, 2021, s. 298. Yazar, olması gereken hukuk bakımından TMK m. 679/II hükmünde mirasçıların paylaşmada her birine özgülenmiş alacağın varlı̆̆ını ve borçlunun ödeme gücünü birbirlerine karşı garanti ettiklerinin hükme bağlanması gerektiğini ileri sürmektedir.

72 BUCHER, 1988, s. 574; FRANKO, 1994, s. 194.

73 ENGİN, 2002, s. 103.

74 TEKINAY/AKMAN/BURCUOĞLU/ALTOP, 1993, s. 266; İsviçre hukukunda aynı yönde bkz. GAUCH/SCHLUEP, 2008, N. 3553. 


\section{Borçlunun Ödeme Gücünün Bulunmaması}

\section{a. Borçlunun Ödeme Gücü Kavramı}

Alacağı devredenin sorumlu olması için, kanundaki ifadeyle "borçlunun ödeme gücü’nün bulunmaması gerekir. Türk Borçlar Kanunu'nda alacağı devredenin garanti sorumluluğuna ilişkin hükümde bu teriminin tercih edildiği görülmektedir. Bu nedenle bu çalışmada da kullanılmış olan terim, çeşitli açılardan eleştiriye açıktır.

6098 sayılı Türk Borçlar Kanunu’nda “ödeme gücü” ifadesinin tercih edilmiş olması, "ödeme”nin, para borçlarının ifasına verilen ad olması sebebiyle eleştirilebilir. Bir diğer ifade ile, ifanın konusu olan edim, bir miktar para ise, ifa yerine "ödeme" terimi kullanılmaktadır. Edimin para olmadığı borç ilişkilerinde ise ifa terimi kullanılır. Devredilen alacak hakkının konusu çoğu zaman paradır, fakat konusunu para dışında bir edimin oluşturduğu alacak hakkı da devredilebilir ${ }^{75}$. Bu ikinci durumda da kanun gereği alacağı devredenin garanti sorumluluğu bulunmaktadır. Hâlbuki "borçlunun ödeme gücünden sorumluluk" ifadesi, para dişındaki edimlerde devredenin garanti sorumluluğunun bulunmadığı izlenimini yaratmaya oldukça elverişlidir. Mehaz İsviçre Borçlar Kanunu'nda "borçlunun ödeme gücünden sorumluluk” ifadesine karşılık gelen terim, ödeme kabiliyeti olarak Türkçe’ye çevrilebilecek olan "Zahlungsfähigkeit" terimidir. Bu terimin olumsuz hali, genel hükümler arasında ödemezlik def’ ine ilişkin OR Art. 83 hükmünde "Zahlungsunfähigkeit” biçiminde kullanılmaktadır. Türk Borçlar Kanunu'nda m. 98 hükmüne karşılık gelen bu hükümde aynı terim “ifa güçsüzlüğ̈̈” olarak Türkçe'ye çevrilmiş ve kanun metnine alınmıştır ${ }^{76}$. Gerçekten de TBK m. 191 hükmünde ifade edilmek istenen sadece para alacakları bakımından değil, devre konu olan diğer edim türleri bakımından da borçlunun ifa güçsüzlüğü içinde olması ve bu nedenle alacağın elde edilememesi, tahsil edilememesidir. Bu yönüyle ifa güçsüzlüğü terimi, ödeme gücü/güçsüzlüğü teriminden daha geniş bir anlam taşımaktadır. TBK m. 98 ve 191 hükümlerinde aynı kavramın (Zahlungsunfähigkeit) ifade edilmeye çalışıldı̆̆

75 GÜNERGÖK, 2014, s. 120; ERCOŞKUN ŞENOL, 2021, s. 292.

76 BK m. 83 ve TBK m. 98 hükümlerinde aciz hali ve ifa güçsüzlüğü kavramlarının aynı anlamda kullanıldığı yönünde bkz. IŞIK, Melih, İcra Hukukunda Borç Ödemeden Aciz Belgesi ve Bu Nitelikteki Haciz Tutanakları (İ́K m. 143,105), On İki Levha Yayınları, İstanbul, 2019, s. 263. 
fakat farklı iki terimin kullanıldığı; bu terimlerden "ifa güçsüzlügüu” teriminin daha isabetli olduğu sonucuna varılmaktadır.

TBK m. 191 hükmüne karşılık gelen 818 sayılı Borçlar Kanunu m. 171/II'de kullanılan terim ise "borçlunun aczi” terimidir. Aciz hali, borçlunun borçlarını, muaccel olmasına rağmen ödeme araçlarının eksikliği veya yokluğu sebebiyle geçici olmayan, devamlılık arz eden ve giderilmesi zor bir ödeme güçlüğü ile karşı karşıya kalmış olması, bununla birlikte henüz borca batık hale gelmemiş derecede mali durumunun bozulması olarak tanımlanmaktadır ${ }^{77} .818$ sayılı Borçlar Kanunu'nun yürürlükte olduğu dönemde, m. 171/II hükmündeki "borçlunun aciz içinde olması"ndan anlaşılması gerekenin, devralanın tüm kanuni yollara başvurmasına rağmen alacağını borçludan tahsil edememesinin ispatlanması olduğu ileri sürülmekteydi ${ }^{78}$. Kanunda bahsi geçen aciz halinin geçici ve bir anlık olmaması; aksine devamlılık taşıması gerektiği savunulmaktayd1 ${ }^{79}$. Fakat 818 sayılı kanunun yürürlükte olduğu dönemde de günümüzde de sorunun usul hukukuna değil, maddi hukuka ilişkin olduğu; bir diğer ifadeyle, devredenin borçlunun ödeme gücünden sorumlu olması için medeni usul, icra ve iflas hukuku bakımından borç ödemeden aciz halinin belgelenmiş olmasının şart olmadığ kabul edilmektedir ${ }^{80}$. Dolayısıyla devralanın, devredenin sorumluluğuna başvurması için iflas veya aciz belgesi almış olması şart değildir.

77 RÜZGARESEN, Cumhur, "Mirasbırakanın Borca Batık Olması", Erzincan Binali Yıldırım Üniversitesi Hukuk Fakültesi Dergisi, Y11: 2010, Cilt: XIV, Sayı: 1-2, s. 276-277; aciz halinin "borçlunun para borçlarını ödeme konusundaki süreli iktidarsızlı̆̆ olduğu" yönündeki tanım için bkz. UMAR, Bilge, "Aciz Hali-Borca Batıklık Kavramlarının Farkı ve Bu Yönden Yeni MK Metninin Düştüğ̈̈ Bir Yanlışlık”, Yeditepe Üniversitesi Hukuk Fakültesi Dergisi, Yı1: 2004, Cilt: I, Sayı: 1, s. 320; IŞIK, 2019, s. 15.

78 DAYINLARLI, 2000, s. 233-234. Öğretide Günergök, devredenin alacağın varlığına ilişkin garanti sorumluluğu ile ilgili açıklamalarında borçlunun borcun geçersiz olduğunu beyan etmesi durumunda devralanın doğrudan devredene başvurabilmesi gerektiğini savunmakta; öncelikle devralan tarafindan borçluya karşı dava açılması veya takip yapılmasının ve bunun sonucunda alacağın geçersiz olduğu sonucuna varılmasının, devredene başvurabilmek için zorunlu olmaması gerektiğini savunmaktadır. Fakat yazar, borçlunun ödeme gücünden sorumluluk bakımından tam tersini savunmakta, önce borçlu aleyhine yasal takibe geçilmiş olmasının gerekli olduğunu savunmaktadır. Bkz. GÜNERGÖK, 2014, s. 123-124.

79 DAYINLARLI, 2000, s. 234.

80 DAYINLARLI, 2000, s. 233; ERCOŞKUN ŞENOL, 2021, s. 292; ENGIN, 2002, s. 123; TEKİNAY/AKMAN/BURCUOĞLU/ALTOP, 1993, s. 262. 
Öğretide Engin'e ${ }^{81}$ göre "borçlunun ödeme gücü” kavramı açıklanırken borçlunun borcu ifa edebilecek durumda olmaması ve borcu ifa edebilecek durumda olmasina rağmen ifa niyetinin bulunmaması (ifa isteksizliği) olasılıkları bakımından ayrı ayrı değerlendirme yapılmalıdır. Alacağı devralanın, alacağını alacak hakkındaki bir eksiklikten ötürü değil de borçlunun borcunu ifa edebilecek durumda olmaması nedeniyle elde edememesi durumunda, bu alacağı cebri icra yoluyla tahsil edebilmesi de şüpheli hale gelmektedir ve devredenin sorumluluğuna başvurmak devralan için son çaredir. Borçlunun borcu ifa edemeyecek durumda olması objektif bir değerlendirmeyi gerektirmektedir. Borçlunun borcu ifa edebilecek durumda olmasına rağmen bundan kaçınması, ifa etme hususunda isteksiz davranması durumunda alacaklının, borcuna sadık olmayan borçluya karşı cebri icra yoluna başvurarak alacağını elde etme imkânı bulunmaktadır. Borçlunun edimi ifa etme hususundaki isteksizliği, tamamen sübjektif bir değerlendirmeyi gerektirmektedir. Bu iki durumdan ilki “ödeme gücü”; ikincisi “ödeme niyeti” olarak adlandırılmaktadır ${ }^{82}$. Bu görüşe göre devredenin borçlunun ödeme gücünden sorumluluğu, borçlunun borcunu ifa etme niyetinin olmaması rizikosunu kapsamamalıdır ${ }^{83}$.

Objektif bir değerlendirmeyi gerektiren “ödeme gücünün bulunmadı̆̆g”nın nasıl tespit edileceği tartışmaya açıktır. Borçlunun ödeme gücünün bulunmaması, en yalın biçimde, borçlunun muaccel hale gelmiş borçlarını ifa edemeyecek durumda olması olarak tanımlanmaktadır ${ }^{84}$. Öğretide savunulan bir görüşe göre, borçlunun ödeme gücünün bulunmadığının sonuçsuz kalmış olan bir icra takibi ile belgelenmesi şart

81 ENGIN, 2002, s. 121-122.

82 ENGİN, 2002, s. 122. Kanaatimizce yazarın kullandığı ödeme gücü ifadesinden borçlunun edimi ifa kabiliyetinin bulunduğunun, ödeme niyetinden de ifa etme niyetinin anlaşılması, devir konusunun para dışındaki edimleri de kapsaması bakımından daha isabetli olacaktır.

83 WEHRLI, 1993, s. 23; ENGİN, 2002, s. 123. Devreden ile devralan arasında akdedilecek bir sözleşme ile devredenin, borçlunun ödeme isteksizliği nedeniyle ifadan kaçınması rizikosunun da üstlenilebileceği hakkında bkz. ERCOŞKUN ŞENOL, 2021, s. 333.

84 ÇABRİ, Sezer, "Karşılıklı Borç yükleyen Sözleşmelerde İfa güçü̈zlüğü ve Buna Bağlanan Sonuçlar", Prof. Dr. Mustafa Dural'a Armağan, Filiz Kitabevi, İstanbul, 2013, s. 417; ERCOŞKUN ŞENOL, 2021, s. 293; ENGİN, 2002, s. 140; TEKİNAY/AKMAN/BURCUOĞLU/ALTOP, 1993, s. 834. 
değildir ${ }^{85}$. Bu görüşe göre borçlunun ödeme güçsüzlüğü içinde olduğu her türlü delille ispatlanabilir.

Alacağın borçlunun ifa güçsüzlüğü içinde olması haricindeki sebeplerle elde edilememesi, örneğin borçluya ulaşılamaması, adresinin bulunmaması ya da başkaca bir sebeple takip gerçekleştirilememesi ${ }^{86}$ durumunda devredenin sorumluluğuna başvurulamaması gerektiği savunulmaktadır. Özellikle, borçlunun bulunamamasının devredenin sorumluluğuna başvurmak bakımından yeterli olmadı̆̆ı ileri sürülmekte ${ }^{87}$, borçlunun bulunamadığı hallerde Tebligat Kanunu'nun ilgili hükümlerine göre tebligat yapılması sağlanarak takibin kesinleştirilmesinin gerektiği belirtilmektedir. Devralandan kaynaklanan sebeplerle alacağın takip ve tahsil edilememiş olması durumunda da devredenin garanti sorumluluğuna başvurulamayacaktır ${ }^{88}$. Özellikle alacağın devralınmasından sonra devralanın fiil ehliyetini kaybetmesi, alacağı elde etmeye yönelik dava ve takip işlerinin gerektiği gibi yürütülmemesi nedeniyle alacağın elde edilememesi halleri, bu son ihtimale örnek olarak gösterilmektedir ${ }^{89}$.

Kanaatimizce, kural olarak alacağı devredenin borçlunun ödeme gücünden sorumlu olması için borçlu aleyhine başvurulan yasal takibin, borçlunun, devir anında, borcunu ödemeye yetecek malvarlığının bulunmaması sebebiyle sonuçsuz kalması ve bu durumun belgelenmesi gerekmektedir ${ }^{90}$. Bu sayede borçlunun ifadan kaçınmasının ifaya ilişkin

85 TEKINAY/AKMAN/BURCUOĞLU/ALTOP, 1993, s. 834-835; UZUN KAZMACI, Özge, Factoring Sözleşmesi, s.151, https://tez.yok.gov.tr/UlusalTezMerkezi/tezDetay.jsp?id=ZI7S5Gje_aR_9qSg KlcniA\&no=ZSV8anU-W6YUbOe7f_a1_A , (erişim tarihi:11.5.2021).

86 GÜNERGÖK, 2014, s. 124-125; ERCOŞKUN ŞENOL, 2021, s. 297. Yazar özellikle devredilen alacağın borçlusunun yasal yollarla ödemeye zorlanamayan ve alacağı keyfi olarak ortadan kaldırabilen egemen devlet olması durumunda devredenin garanti sorumluluğunun var olmayacağını ileri sürmektedir. Bkz. s. 297, dpn. 1092'deki yazarlar.

87 GÜNERGÖK, 2014, s. 125.

88 ERCOŞKUN ŞENOL, 2021, s. 296.

89 OĞUZMAN/ÖZ, C. II, 2018, s. 598; ERCOŞKUN ŞENOL, 2021, s. 296; ÜÇER, 2005, s. 427.

90 İsviçre hukukunda da devredenin borçlunun ödeme gücünü üstlendiği hallerde devralanın borçluya sadece başvurmuş olmasının devredenin sorumluluğuna başvurabilmek için yeterli olmadığı yönünde bkz. GAUCH/SCHLUEP, 2008, N. 3510. Aynı yönde bkz. Yargitay 15. Hukuk Dairesi, 24.01.2018 tarihli ve 2016/4990 E., 2018/200 K. "Borçlunun ödeme gücü bulunmadığından söz edebilmek için alacağı devralanın asıl borçluya karşı hukuki yolları tüketmesi gerekir. Alacağın tahsili için hukuki yollara başvurmaksızın ivazlı temlik sorumluluğu nedeniyle devredenden doğrudan talepte bulunması mümkün değildir (Yargitay 15. HD. 10.11.2014 tarih 2014/4301 Esas 2014/6477 Karar). Diğer bir ifadeyle alacağı devralanın devredene rücu edebilmesi yani temlik edenin sorumlu tutulabilmesi, borçludan alacağının tahsili için gerekli her çareye başvurmuş olmasına rağmen alacağını tahsil 
isteksizliğinden mi, yoksa ifa güçsüzlügü içinde bulunmasından mı kaynaklandığı da tespit edilmiş ve devredenin sorumluluğunun bu şartı objektif olarak temellendirilmiş olacaktır. Bir yandan da borçlu aleyhine takip başlatılamayacağının veya borçlunun ifa güçsüzlüğü içinde olduğunun apaçık ortada olduğu hallerde, alacağı devralanın önce borçluyu takip etmesi gerektiğini savunmak hiçbir amaca hizmet etmemektedir. Böyle bir durumda devralan takip için gereksiz masraf yapacak, zaman kaybedecek, belki de devredene başvurabileceği zamanaşımı süresini kaçıracaktır. Bu nedenle oldukça sınırlı bazı hallerde devralan, borçluyu takip etmeksizin doğrudan doğruya devredenin sorumluluğuna başvurabilmelidir. O halde, borçlunun iflas etmesi, haczin sonuçsuz kalması, borçlunun ödemelerini tatil etmiş olması, işletmesini kapatması, adresini ve izini kaybettirmesi, kambiyo senedine bağlanan borçlar için protesto çekilmesi veya bankalarda karşılığının bulunmaması, uzun süreli borç erteleme isteği, ödemelerin durdurulması, alacaklılar ile konkordato yapmak için icra mahkemesine başvurması ${ }^{91}$, borçlunun diğer borç ilişkilerinde ifada sürekli olarak gecikmesi, borçlu hakkında iflasın ertelenmesi kararı verilmesi gibi haller ${ }^{92}$, ifa güçsüzlügüünün göstergesi olarak değerlendirilmeli ve bu hallerde alacağı devralan, devredenin garanti sorumluluğuna başvurabilmelidir.

\section{b. Devredenin Kime Karşı ve Borçlunun Hangi Andaki Ödeme Gücünden Sorumlu Olduğunun Belirlenmesi ve İspat Sorunu}

Alacağ1 devredenin garanti sorumluluğu, devir sözleşmesinin tarafları arasında söz konusudur. Bir diğer ifadeyle alacak birden fazla kez devredilmişse, her bir devreden, alacağı devrettiği yeni devralana karşı borçlunun ödeme gücünden sorumludur ${ }^{93}$. Bununla

edemediği hususunu ispat etmesi koşuluna bağlıdır (Yargıtay 4. Hukuk Dairesi'nin 04.05.1965 gün, 1965/2342-2383 E.K, 11. Hukuk Dairesi'nin 03.01.1980 gün 1980/80-401 E.K, 13. Hukuk Dairesi'nin 03.04.1986 gün 1986/1275-1998 E.K ve yine 13. Hukuk Dairesi’nin 06.07.2009 gün 2009/5396-9350 E.K sayılı ilâmları).”, kararın tam metni için https://29b13951316a490bc215ebb98f180002769de725.vetisonline.com/ictihat/yargitay/15-hukukdairesie2016-4990- k-2018-200-t-24-1-2018 (erişim tarihi: 23.05.2021).

91 Alacaklıların konkordato talep etmesinin borçlunun ifa güçsüzlüğü içinde bulunduğunu belirlemek bakımından yeterli olmadığı yönünde bkz. ÇABRİ, 2013, s. 422.

92 ÇABRİ, 2013, s. 420; EREN, Fikret, Borçlar Hukuku Genel Hükümler, 23. Baskı, Yetkin Yayınları, Ankara, 2018 (EREN, 2018, a), s. 1025; IŞIK, 2019, s. 265.

93 BUCHER, 1988, s. 574; WEHRLI, 1993, s. 19; TUNÇOMAĞ, 1976, s. 1102; GÜNERGÖK, 2014, s. 113. 
birlikte, alacağı devreden, bu alacağı daha sonra devrettiği kişiden devralanlara karşı da borçlunun ödeme gücünden sorumlu olmayı üstlenebilir. Devredenin bu yönde açık bir iradesi bulunmadıkça, alacağı devrettiği kişiden devralanlara karşı borçlunun ödeme gücünden sorumluluğu bulunmamaktadır.

Devredenin, borçlunun hangi andaki ödeme gücünden sorumlu olduğunun belirlenmesi de önem arz eden konulardan biridir. Bu belirleme yapılırken hem TBK $\mathrm{m}$. 191/I hükmünde yer alan “...devir sırasında... borçlunun ödeme gücüne sahip olduğunu..." ifadesinin; hem de borcun devir sırasında muaccel olup olmadığının dikkate alınması gerekmektedir. Öyle ki, alacak hakkının devrine ilişkin borçlandırıcı işlem yapıldığında borçlu ifa güçsüzlüğü içinde olabilir, alacak devredilirken borçlunun ifa kabiliyeti bulunmasına rağmen devirden sonra fakat borç muaccel olmadan önce borçlu ifa güçsüzlüğü içine düşebilir ya da henüz muaccel olmamışken devredilen alacağın borçlusu, borç muaccel olduktan sonra ifa güçsüzlüğü içine düşebilir.

Kanunda "devir sırasında ... borçlunun ödeme gücüne sahip olduğunu” ifadesinden alacağın devrine ilişkin borçlandırıcı işlemin yapıldığı anın mı, yoksa tasarruf işlemi niteliğindeki devir sözleşmesinin yapıldığı anın mı kastedildiği belirlenmelidir. Öğretide devredenin garanti sorumluluğunun alacağın devrinin sebebini oluşturan borçlandırıcı işlemden kaynaklandığı savunulmaktadır ${ }^{94}$. Borçlandırıcı işlem ile tasarruf işleminin aynı anda gerçekleştiği haller bakımından "devir sırasında... borçlunun ödeme gücüne sahip olduğunu" ifadesinden ne anlaşılması gerektiği hususu, tereddüt yaratmamaktadır. Fakat bu iki işlemin arasına bir zaman diliminin girdiği hallerde "devir sırasında" ifadesinden borçlandırıcı işlemin tarihinin $\mathrm{mi}$, tasarruf işleminin tarihinin mi borçlunun ifa kabiliyetine sahip olup olmadığının belirlenmesinde esas alınacağı önem arz eder. Kanaatimizce, borçlunun ödeme gücünün var olup olmadığının belirlenmesinde tasarruf işleminin yapıldığı an esas alınmalıdır. Bu çözüm tarzı, alacağı devredenin kanundan doğan bir tekeffül sorumluluğu olan garanti sorumluluğunun hukuki niteliğinin hukuki ayıptan doğan sorumluluğa benzetilmesi ile de uyumludur. Zira ayıptan doğan

94 FÄSSLER, 2010, N. 490; OĞUZMAN/ÖZ, C. II, 2018, s. 595; ENGIN, 2002, s. 66. 
sorumluluğun başlangıcı, yarar ve hasarın geçtiği andır ${ }^{95}$. Bir diğer ifadeyle mülkiyeti devir borcu doğuran sözleşmelerde aksi kararlaştırılmadıkça hasarın geçişinden önce, en geç hasarın geçtiği andaki ayıptan sorumluluk söz konusudur ${ }^{96}$. Bu an satış sözleşmesine ilişkin TBK m. 208/I hükmünde taşınırlarda zilyetliğin devri, taşınmazlarda ise tescil tarihi olarak öngörülmüştür. Kanun koyucu yarar ve hasarın geçtiği anı, tasarruf işleminin yapıldığı an olarak açıkça belirlediğine göre, alacağın devri bakımından da aynı sonuca ulaşılması gerekir. Tasarruf işlemi niteliğindeki devir sözleşmesinin akdedildiği tarihte borçlunun ödeme gücünün bulunmaması halinde, devredenin garanti sorumluluğu gündeme gelmelidir ${ }^{97}$. Hasar ve yararın geçişinden sonraki ayıplar kasıtlı olarak gizlenmişse ya da hasar ve yararın geçişinden sonraki ayıplar -devreden tarafından- özel olarak üstlenilmiş olmadıkça sorumluluk kapsamında değildir ${ }^{98}$. Buna paralel olarak, alacak devredilirken borçlunun ödeme gücü bulunmuyorsa ve devralan da borçlunun ödeme gücünün bulunmadığını biliyorsa, devredenin açıkça üstlenmedikçe borçlunun ödeme gücünden sorumlu olmaması gerektiği sonucuna ulaşılabilir.

Alacağı devredenin borçlunun ödeme gücünden sorumluluğunun belirlenmesinde değerlendirilmesi gereken bir diğer husus da devir sırasında alacağın muaccel olup olmadığı hususudur. Öğretide devredenin, borçlunun ödeme gücünden sorumlu olması için devredilen alacağın devir sırasında muaccel olmasının gerekmediği; alacağın devirden daha sonra muaccel olması ihtimalinde ise, devredenin, borçlunun muacceliyet

95 Satış sözleşmesinde yarar ve hasarın geçiş anı hakkında ayrıntılı açıklamalar için bkz. ÇETiNER, Bilgehan, "Yeni Türk Borçlar Kanunu'nda Yarar ve Hasarın İntikali ile Satıcının Ayıptan Sorumluluğuna İlişsin Hükümlerin Değerlendirilmesi”, İstanbul Üniversitesi Hukuk Fakültesi Mecmuası, Y11: 2009, Cilt: 67, Sayı: 1-2, s. 99 vd.

96 EREN, Fikret, Borçlar Hukuku Özel Hükümler, 6. Baskı, Yetkin Yayınları, Ankara 2018 (EREN, 2018, b), s. 114. Öğretide Oğuzman/Öz, devredenin garanti sorumluluğu bakımından bu anın esas alınmasının teorik olarak tutarlı, fakat pratik açıdan sakıncalı olduğunu belirtmektedir. Bkz. OĞUZMAN/ÖZ, C. II, 2018, s. 599.

97 Öğretide Dayınlarlı, konuya ilişkin olarak şu açıklamayı yapmaktadır: "Federal Mahkemenin yorumuna göre ise, borçlunun ödeme gücünün garantisi için temlik edenin sorumluluk zamanı, temlik muamelesinin tamamlandı̆̆̆, muhtemelen alacağın muaccel olduğu andır; fakat bu andan daha sonraki bir zaman değildir.”. Bkz. DAYINLARLI, 2000, s. 235.

98 EREN, 2018, b, s. 114. Alacağı devredenin, devralanı, borçlunun ödeme gücü konusunda aldatması halinde aldatma hükümlerinin uygulama alanı bulacağı ve sözleşmenin iptal edilebileceği hakkında bkz. ENGIN, 2002, s. 137. Devredenin aldatması durumunda devrin edim karşıllğı olup olmaması önem taşımaksızın sorumluluğunun doğacağı hakkında bkz. WEHRLI, 1993, s. 19. 
anına kadarki ödeme gücünden sorumluluğunun söz konusu olacağı savunulmaktadır ${ }^{99}$. $\mathrm{Bu}$ görüşe göre, hayatın olağan akışı içinde alacak muaccel olmadan borçluya başvurulmayacağı için borçlunun ödeme gücünün bulunup bulunmadığı çoğu zaman bu aşamaya kadar bilinemeyecektir. Gerçekten de, borçlunun borcunu ifa edip etmeyeceği, edemeyecekse bunun ifa güçsüzlüğünden kaynaklanıp kaynaklanmadığı, çoğu zaman ancak muacceliyet ile açığa çıkabilir. Bununla birlikte, devredenin borçlunun hangi andaki ödeme gücünden sorumlu olduğunun da objektif biçimde belirlenebilmesi ihtiyacı ortadadır. Devirden sonra fakat muacceliyet tarihinden önce ifa güçsüzlügü içine düşen borçlunun bu durumu, devir tarihinde bilinebilir veya öngörülebilir nitelikte olmadı̆̆ 1 için bu belirsizliğin barındırdığı rizikonun devredene yükletilmesi, devralanın gereğinden fazla korunması sonucunu doğurabilir. Kanaatimizce, devir sırasında alacağın muaccel olup olmamasının, borçlunun ödeme gücünün belirleneceği an bakımından önem taşımaması gerektiğini savunmak, TBK m. 191/I hükmünün lafzıyla paralellik ve tutarlılık taşır. Bu sonuç kabul edilecek olursa, devir sırasında ödeme gücü bulunan borçlu, borç muaccel olana kadar bu gücünü kaybederse, devredenin sorumluluğu gündeme gelmemelidir. Borçlunun ödeme gücünün bulunmadığının tespiti, alacağın muaccel olduğu tarihe kadar ötelenecek olursa, bu belirsizlik, devredenin son derece aleyhine sonuçlar doğurabilir. Alacağı devredenin garanti sorumluluğu devralan lehine bir tür teminat olduğuna göre, teminat hukukunun genel prensiplerinden olan rizikonun belirliliği ilkesine riayet edilmesi gerekir. Devreden, borçlunun devir anından sonraki ödeme gücünü bilemeyeceğine ve değerlendiremeyeceğine göre, bundan sorumlu da tutulmamalıdır. Devir sırasında muaccel olmayan bir alacak devredildiğinde, bu alacak, devir anında muaccel olsaydı borçlunun ifa güçsüzlüğü içinde olması nedeniyle devralanın alacağı elde edemeyeceği açıkça anlaşılıyorsa, ancak bu olasılıkta devreden bundan sorumlu olmalı, aksi halde devredenin sorumluluğu gündeme gelmemelidir.

99 TEKINAY/AKMAN/BURCUOĞLU/ALTOP, 1993, s. 262; GÜNERGÖK, 2014, s. 114. Devredenin borçlunun ödeme gücünden sorumluluğu sözleşme ile üstlenebildiği İsviçre hukukunda da akis sözleşmede belirtilmemişse aynı yöndeki sonuç için bkz. BECKER, 1945, Art. 171, N. 13; FÄSSLER, 2010, N. 264; REETZ/BURRI, 2016, Art. 171, N. 8. Avusturya hukukunda aynı yönde bkz. NEUMAYR, 2007, s. 1641, N. 2. Öğretide devredenin, devir tarihinden, alacağın zamanaşımına uğradığ 1 def'i geçerli biçimde ileri sürülene kadar borçlunun ödeme gücünden sorumlu olduğu yönünde bkz. ERCOŞKUN ŞENOL, 2021, s. 302-303. 
Alacağı devredenin, borçlunun muacceliyet anındaki ödeme gücünden sorumluluğunun kabulü, bir başka sakıncayı daha beraberinde getirmektedir: Muacceliyetin alacaklının muacceliyet ihbarında bulunması ile gerçekleştiği hallerde alacağı devralanın bu ihbarda bulunaktan kaçınması, borçlunun ödeme gücünün belirleneceği anın devreden aleyhine belirlenebilmesine zemin hazırlayacaktır ${ }^{100}$. Alacağ 1 devredenin garanti sorumluluğuna ilişkin hükümler emredici nitelik taşımadıkları için, tarafların, sözleşme ile farklı hükümler belirlemelerine bir engel bulunmamaktadır. Sözleşme ile, alacağı devredenin, borçlunun hangi andaki ödeme gücünden sorumlu olduğu kararlaştırılabilir. Böyle bir sözleşme hükmü bulunmadığı sürece, devredenin, borçlunun objektif biçimde belirlenebilecek devir anındaki ödeme gücünden sorumlu tutulması daha isabetli görülmektedir ${ }^{101}$.

Devredenin, borçlunun hangi andaki ödeme gücünden sorumlu olduğunun doğru tespiti, ispat bakımından önem taşımaktadır. Alacağı devredenin sorumluluğuna başvurmak isteyen devralan, borçlunun -kanaatimizce- devir anında ödeme gücünün bulunmadığını ispat yükü altındadır ${ }^{102}$. Borçlunun ödeme gücünün bulunmadığı her türlü delille ispatlanabilir ${ }^{103}$.

\section{BORÇLUNUN ÖDEME GÜCÜNDEN SORUMLULUĞUN SONUÇLARI 1. Genel Olarak}

Alacağ1 edim karşılığı devralan, yukarıda sayılan şartların oluştuğu hallerde, alacağını tahsil edemezse, devredenin garanti sorumluluğuna başvurarak alacağı elde etmeye çalışabilir. Devredenin sorumlu olduğu tutar, devredilen alacak olmayıp, bu

${ }^{100} \mathrm{Bu}$ hallerde devredenin borçlunun ödeme gücünden sorumluluğunun, vadeye göre belirlenecek en erken fesih tarihine kadar devam edeceği yönünde bkz. BGE 61 II 102/104 f. E. 2, BGE 63 II 14/17 E. 5, karar özetleri için bkz. KRAUSKOPF, 2016, Art. 171, N. 7.

${ }^{101}$ Aksi yönde bkz. ENGIN, 2002, s. 133-134. Aynı yönde bkz. LARDELLI, 2014, Art.171, N. 7. Zira İsviçre hukukunda edim karşıllı̆ı devirlerde devredenin borçlunun ödeme gücünden garanti sorumluluğu kanunda öngörülmeyip sözleşme ile kararlaştıııldığı için, sözleşme ile, borçlunun devir anından daha farklı bir zamandaki ödeme gücünden sorumlu olunacağının kararlaştırılabileceği kabul edilmektedir.

102 FÄSSLER， 2010, N. 265; TEKINAY/AKMAN/BURCUOĞLU/ALTOP， 1993， s. 262; REETZ/BURRI, 2016, Art. 171, N. 8; OĞUZMAN/ÖZ, C. II, 2018, s. 598; ENGİN, 2002, s. 135. Yazar, devir veya muaccel olmadan devredilen alacaklarda muacceliyet anında borçlunun ödeme gücünün bulunmadığının ispatlanması gerektiğini belirtmektedir.

103 TEKİNAY/AKMAN/BURCUOĞLU/ALTOP, 1993, s. 262. 
alacağın karşılığını oluşturan edim ve kanunda sayılan diğer bazı alacak kalemleridir ${ }^{104}$. TBK m. 193 hükmü uyarınca devralan, garanti ile yükümlü olan devredenden,

1. Ifa ettiği edimin faizi ile birlikte geri verilmesini,

2. Devrin sebep olduğu giderleri,

3. Borçluya karşı devraldiğı alacă̆ı elde etmek için yaptığı ve sonuçsuz girişimlerin yol açtığl giderleri

4. Devreden kusursuzluğunu ispat etmedikçe uğradı̆̆ı diğer zararlarını talep edebilir.

Hükümde sayılan ilk üç alacak kalemi, devredenin kusurlu olup olmamasından bağımsız biçimde devredene yüklenmiştir. Dördüncü kalem ise TBK m. 112 hükmündeki kusur karinesine paralel bir düzenleme olup, devreden kusursuzluğunu ispatlayarak “diğer zararlar”' tazmin etmekten kurtulabilir ${ }^{105}$.

Alacağı devredenin borçlunun ödeme gücünden sorumluluğun, ikincil (tâli) bir sorumluluk olup olmadığı da önem arz eden konulardan biridir. Türk Borçlar Kanunu’nda bu konuya ilişkin açık bir düzenleme yer almamaktadır. Fakat devredenin garanti sorumluluğunun özellikleri ve bu sorumluluğa ilişkin hükümler birlikte değerlendirildiğinde anlamlı bir sonuç ortaya çıkmaktadır: Alacağın devredilmesi ile birlikte devralan, asıl alacakla birlikte öncelik haklarını ve bağlı hakları (örneğin teminatları ve işlemiş ve işleyecek faizi) da devralmış olur (TBK m. 189). Ayrıca devredenin garanti sorumluluğunun kapsamına ilişsin ilişkin TBK m. 193 hükmünün, dördüncü bent haricinde olumsuz zararları işaret ettiği kabul edilmektedir ${ }^{106}$. İlk üç bentte alacağı devralanın devir konusu alacağı elde etmiş olsaydı sağlayacağı menfaatin değil; böyle bir devir yapılmamış olsaydı uğranılmayacak olan zararın talep edilebileceği

104 OĞUZMAN/ÖZ, C. II, 2018, s. 600.

105 OĞUZMAN/ÖZ, C. II, 2018, s. 600.

106 TEKİNAY/AKMAN/BURCUOĞLU/ALTOP, 1993, s. 263. İsviçre Borçlar Kanunu'nun TBK m. 193 hükmüne karşılık gelen Art. 173'te de sadece olumsuz zararların tazminine imkân tanınmıştır. Bkz. LARDELLI, 2014, Art.173, N.1-2; FÄSSLER, 2010, N. 486. Öğretide 193 hükmündeki alacak kalemlerinin olumlu ve olumsuz zarar olarak değil, doğrudan zarar ve dolaylı zarar olarak tasnif edilmesi gerektiği hususunda bkz. ERCOŞKUN ŞENOL, 2021, s. 327-328. 
savunulmaktadır ${ }^{107}$. 6098 sayılı Türk Borçlar Kanunu'na 818 sayılı Borçlar Kanunu'ndan farklı olarak eklenen dördüncü bentte ise, kusur şartına bağlanmış olan “diğer zararlar" sorumluluğun kapsamına dahil edilmiştir. Garanti sorumluluğunun kapsamını oluşturan karşı edim ve faizi, devrin sebep olduğu giderler, alacağı elde etmek için yapılan masraflar; devralanın sorumluluğuna başvurulabilmesi için öncelikle devredenin borçluya karşı harekete geçmesinin gerektiğini gösterir. Devralanın doğrudan doğruya devredene başvurabilmesi, asıl borçluyu ifaya hiç zorlamaksızın ifayı devredenden talep etmesi kabul edilecek olursa, özellikle TBK m. 193/I, b. 3'te ifade edilen borçluya karşı alacağı elde etmek için yapılan sonuçsuz girişimlerin devredenin sorumluluğunun kapsamında olmasının anlamı açıklanamazdı. Hâlbuki devir işlemiyle birlikte teminatları da devralmış olan devralanın önce borçluya ve teminatlara; daha sonra ikincil olarak devredenin garanti sorumluluğuna başvurması gerekir. Aksi halde borçlu ile aynı seviyede sorumlu olacağı iddia edilen devredenin, kanun gereği bağlı hakları ve teminatları devralana devretmiş olmasının anlamı ve işlevi açıklanamaya muhtaç olacaktır. Bu nedenlerle alacağı devredenin, borçluyla birlikte birincil bir sorumluluğu değil; borçlunun ifa güçsüzlüğünün ve alacağın tahsil edilemeyeceğinin anlaşılmasıyla, borçlunun ve borcu temin etmek üzere verilmiş teminatların ardından gelen bir sorumluluğunun bulunduğu kabul edilmelidir ${ }^{108},{ }^{109}$.

Son olarak, alacağı devreden ile devralan arasında, devredenin, borçlunun ödeme gücünden sorumlu olmayacağının öngörüldüğü bir sorumsuzluk anlaşması yapılırsa; bu anlaşmanın devredenin garanti sorumluluğuna etkisi değerlendirilmelidir. Alacağ1 devredenin garanti sorumluluğuna ilişkin hükümler emredici nitelik taşımadıkları için, taraflarca bu sorumluluğun belirli bir süreye tâbi olması, ortadan kaldırılması ya da kapsamının daraltılması mümkündür. Fakat, sorumsuzluk anlaşmaları, TBK m. 115'te öngörülen sınırlamalar çerçevesinde akdedilebilir. Dolayısıyla borçlunun (devredenin)

107 HATEMİ/ GÖKYAYLA, 2015, 383; TEKINAYY/AKMAN/BURCUOĞLU/ALTOP, 1993, s. 263.

108 Bkz. TEKINAY/AKMAN/BURCUOĞLU/ALTOP, 1993, s. 261, dpn. 24; GÜNERGÖK, 2014, s. 124, devredenin alacağın varlığına ilişkin garanti sorumluluğu hakkında aynı sonuç için bkz. LARDELLI, 2014, Art.171, N. 3.

109 Alacağı devredenin garanti sorumluluğunun, alacağın teminatlarının borçlularının ödeme gücünü kapsamadığı yönünde bkz. VON TUHR/ESCHER, 1974, s. 355. 
ağır kusurundan sorumlu olmayacağına ilişkin devralan ile önceden yapılan anlaşmalar TBK m. 115/I hükmü uyarınca kesin hükümsüzdür. Böyle bir ihtimalde, devredenin, borçlunun ödeme gücünün varlığına ilişkin garanti sorumluluğu bulunmaktadır ${ }^{110}$. Sorumsuzluk kaydı devir sözleşmesinde yer alıyorsa, sözleşmenin sadece bu kısmı hükümsüz kabul edilmeli, devir sözleşmesinin diğer hükümleri varlığını ve geçerliliğini sürdürmelidir ${ }^{111}$.

\section{Sorumluluk Kapsamında Talep Edilebilecek Alacaklar}

\section{a. Devredenin kusuruna bağlı olmaksızın talep edilebilen alacaklar}

Alacağ1 devredenin garanti sorumluluğunun doğması durumunda alacaklının, devredene yöneltebileceği taleplerinin TBK m. 193 hükmünde düzenlendiği belirtilmişti. Devralanın talep edebileceği alacak kalemlerinin sınırlandırıldığı bu hüküm uyarınca, devredenin, kusurlu olup olmamasından bağımsız olarak "ifa ettiği edimin faiziyle birlikte geri verilmesine, devrin sebep olduğu giderlere, borçluya karşı devraldığı alacağı elde etmek için yaptığı ve sonuçsuz girişimlerin yol açtığg giderlere ilişkin taleplerle karşılaşması mümkündür.

Devralan esas olarak devraldığı alacağı değil, bu alacak için ödediği karşılığ1 faiziyle birlikte devredenden talep edebilir ${ }^{12}$. Örneğin bir ay sonra vadesi gelecek olan yüz bin TL'lik alacağı doksan beş bin TL karşılığında devralıp borçlunun ödeme gücünün bulunmaması nedeniyle alacağını tahsil edemeyen devralan, devredenin garanti sorumluluğuna başvurduğunda; ondan alacak miktarını değil, bu alacağı devralma karşılığında ödediği karşılığı talep edebilir. Devralan bu alacağın bir kısmını borçludan tahsil etmişse, devredenden, ona ödediği karşılık ile borçludan tahsil ettiği kısım arasındaki farkı talep edebilmelidir ${ }^{113}$. Talep edilebilecek faiz, kaynağını bir kanun hükmünden almaktadır"114 ve oranı TBK m. 88 ve 3095 sayılı "Kanuni Faiz ve Temerrüt

\footnotetext{
110 ERCOŞKUN ŞENOL, 2021, s. 313.

111 ERCOŞKUN ŞENOL, 2021, s. 313.

112 TEKINAY/AKMAN/BURCUOĞLU/ALTOP, 1993, s. 263; NEUMAYR, 2007, s. 1642, N. 3.

113 TEKINAY/AKMAN/BURCUOĞLU/ALTOP, 1993, s. 263; ENGİN, 2002, s. 150; GÜNERGÖK, 2014, s. 127-128; ERCOŞKUN ŞENOL, 2021, s. 319.

${ }^{114}$ LARDELLI, 2014, Art.173, N. 2; DAYINLARLI, 2000, s. 269; ERCOŞKUN ŞENOL, 2021, s. 320.
} 
Faizine İlişkin Kanun”'a göre belirlenecektir. Alacağın devrinin ticari iş niteliğinde olması durumunda avans faiz oranı uygulanır. $\mathrm{Bu}$ faizin devredene yapılan kazandırma tarihinden itibaren işlemesi gerektiği kabul edilmektedir ${ }^{115}$. Devredene, alacağın karşılığında para dışında bir malvarlığı kazandırılacak olursa, bu takdirde alacağı elde edemeyen devralan, devreden lehine gerçekleştirdiği kazandırmanın aynen iadesini, bu mümkün değilse kazandırmanın parasal değerini faiziyle talep edebilir ${ }^{116}$. Bu karşılığın hangi andaki değerinin esas alınacağ 1 önem taşımaktadır. Kanaatimizce, devreden lehine kazandırmanın gerçekleştiği tarihteki değer esas alınmalıdır.

Alacağı devralan, garanti sorumluluğuna başvurduğu devredenden, devrin sebep olduğu giderleri de talep edebilir. Alacağın devri için yapılan işlem masrafları, noter giderleri bu kapsamda değerlendirilmektedir. Ayrıca alacağın devri sözleşmesine ilişkin borçlandırıcı işlem için de masraf yapılmış olması ihtimalinde, bu masrafların da devredenin garanti sorumluluğunun kapsamında olduğu kabul edilmektedir ${ }^{117}$.

Alacağ 1 devralan, borçluya karşı alacağı elde etmek için yaptığı ve sonuçsuz kalan girişimlerin neden olduğu giderleri de garanti sorumluluğuna başvurduğu devredenden talep edebilir. Özellikle alacağı tahsil etmek için zorunlu olarak yapılmış olan dava ve takip masrafları, yargılama harçları, tebligat masrafları bu kapsamda değerlendirilmektedir ${ }^{118}$.

\section{b. Devredenin kusuruna bağlı olarak talep edilebilen alacaklar}

Alacağı devredenin garanti sorumluluğu kapsamında devralanın talep edebileceği alacak kalemleri TBK m. 193 'te dört bent halinde sayılmıştır. Dördüncü bentte, ilk üç bentten farklı olarak devralanın "devreden kusursuzluğunu ispat etmedikçe uğradiğı diğer zararlarını" devredenden talep edebileceği belirtilmiştir. Diğer üç bentte ise devredenin kusuru ya da kusursuzluğu önem taşımamaktadır. Bu ihtimalde, devralan, uğradığı diğer zararların oluşmasında devredenin kusurunu ispatlamayacak; devreden, kendi

\footnotetext{
115 ENGIN, 2002, s. 150; ERCOŞKUN ŞENOL, 2021, s. 321.

116 ENGIN, 2002, s. 150; GÜNERGÖK, 2014, s.128; ERCOŞKUN ŞENOL, 2021, s. 318.

117 VON TUHR/ESCHER, 1974, s. 346; ERCOŞKUN ŞENOL, 2021, s. 322.

118 ERCOȘKUN ȘENOL, 2021, s. 323.
} 
kusursuzluğunu ispatlayacaktır ${ }^{119}$. Devralanın diğer zararlarına örnek olarak devralanın üçüncü kişilere karşı taahhütlerini yerine getirememesi nedeniyle doğan zararlar gösterilmektedir ${ }^{120}$.

\section{ZAMANAŞIMI}

Alacağı devredenin garanti sorumluluğu, ilelebet devam eden bir sorumluluk değildir. Bununla birlikte alacağı devredenin garanti sorumluluğunun tabi olduğu zamanaşımı süresi kanunda özel olarak düzenlenmemiştir. Konunun hem devredilen alacağın hem de garanti sorumluluğunun tabi olduğu zamanaşımı süresi bakımından değerlendirilmesi gerekmektedir. Devredilen alacak zamanaşımına uğrayana kadar devredenin sorumluluğunun devam edeceği; alacak zamanaşımına uğradıktan sonra, borçluya ve sonrasında da devredene karşı alacağı elde etmek üzere herhangi bir girişimde bulunmayan devralanın, bu olumsuz sonuca katlanmak zorunda kalacağı ileri sürülmektedirr ${ }^{121}$. Devredenin garanti sorumluluğu bakımından ise öğretide ${ }^{122}$ genel zamanaşımı (TBK m. 146) süresi olan 10 yıllık zamanaşımı süresinin uygulanması gerektiği savunulmaktadır. Bu görüşe göre devredilen alacağın daha kısa veya uzun zamanaşımı süresine tabi olduğu hallerde de garanti sorumluluğunun on yıllık zamanaşımı süresine tabi olması gerektiği kabul edilmektedir. Kanaatimizce alacağı devredenin garanti sorumluluğu, kaynağını kanundan alan ve devir sözleşmesinden bağımsız bir niteliği bulunmayan bir sorumluluk olduğuna göre; devir sözleşmesine konu olan alacağın tâbi olduğu zamanaşımı süresi, devredenin garanti sorumluluğu bakımından da uygulanmalıdır. İsviçre hukukunda ve 818 sayılı Borçlar Kanunu'nun yürürlükte olduğu dönemde her halûkarda on yıllık zamanaşımı süresinin uygulanması gerektiğinin savunulma sebebi, edim karşılığı devirlerde borçlunun ödeme gücünden sorumluluğun kanundan kaynaklanmaması; bunun yerine devreden tarafında açıkça üstlenildiği hallerde var olmasıdır. $\mathrm{Bu}$ nedenle gerek İsviçre hukukunda gerekse 818 sayılı Borçlar

119 GÜNERGÖK, 2014, s. 128.

${ }^{120}$ HATEMI/ GÖKYAYLA, 2015, s. 383.

121 GÜNERGÖK, 2014, s. 116.

${ }^{122}$ LARDELLI, 2014, Art.171, N. 2; REETZ/BURRI, 2016, Art. 171, N. 3; ENGIN, 2002, s. 153, dpn. 15; WEHRLI, 1993, s. 18; aynı yönde bkz. BGE 53 II 111/117, ilgili karar için bkz. KRAUSKOPF, 2016, N. 6. 
Kanunu'nun yürürlükte olduğu dönemde benimsenen bu yaklaşım kendi içinde tutarlıdır. Fakat TBK m. 191 hükmünden kaynağını alan ve devir sözleşmesinden bağımsız bir varlığı bulunmayan garanti sorumluluğu için devrin konusu alacağın tabi olduğu zamanaşımı süresinin uygulanması daha isabetli görülmektedir.

\section{SONUÇ}

6098 sayılı Türk Borçlar Kanunu'nun alacağın devrine ilişkin hükümleri arasında, 818 sayılı borçlar Kanunu'ndan farklı olarak devredenin, borçlunun ödeme gücünden devralana karşı garanti sorumluluğu düzenlenmiştir. Kanunda tercih edilmiş olan "borçlunun ödeme gücü” ifadesi terminolojik olarak isabetli olmayıp, bu terimden anlaşılması gereken, borçlunun ifa güçsüzlüğünden sorumluluktur. Bu sorumluluğun kanunda öngörülmüş olması, devreden aleyhine son derece önemli ekonomik sonuçları da beraberinde getirmektedir. Hukuki niteliği kanundan kaynaklanan bir tekeffül (sağlama) borcu olarak öngörülen sorumluluk, hem sorumluluğu doğuran olgular hem de -özellikle henüz muaccel olmamış borçlar için- sorumluluğun başladığı an bakımından son derece dar yorumlanması gereken bir hüküm olarak görülmelidir. Alacağı devredenin borçlunun ödeme gücünden sorumluluğun, tâli bir sorumluluk olarak değerlendirilmesi gerekmektedir. Sorumluluğun tâlilik özelliğine, kanunda alacağın devrine ilişkin hükümlerin bir bütün olarak yorumlanması ile ulaşılabilmektedir. Bu nedenle alacağın önce asıl borçludan ve varsa devralana intikal etmiş teminatlardan elde edilmeye çalışılması, bu çabalar ve araçlar sonuçsuz kaldıktan sonra devredenin kanundan kaynaklanan garanti sorumluluğuna başvurulması gerekmektedir. Alacağı devredenin garanti sorumluluğuna başvuran devralanın, talep edebileceği alacak kalemleri kanunda sayılmış olup, devralanın bu talebi, devredilen alacağın tâbi olduğu zamanaşımı süresine tâbi olmalıdır. 


\section{KAYNAKÇA}

AKSOY, Hüseyin Can, “Alacağ1 Temlik Edenin Kanundan Doğan Garanti Sorumluluğunun Ekonomi Hukuku Prensipleri Işı̆̆ında Değerlendirilmesi”, Ankara Barosu Dergisi, Yı1: 2021, Sayı: I, (s. 141-160).

ARAL, Fahrettin, Kötü İfa, Yetkin Yayınları, Ankara, 2011.

BECKER, Herman, Berner Kommentar, Allgemeine Bestimmungen, Art. 1-183 OR Schweizerisches Zivilgesetzbuch, Obligationenrecht, Stämpfli Verlag AG, Bern, 1945.

BUCHER, Eugen, Schweizerisches Obligationenrect Allgemeiner Teil onhe Deliktsrect, 2. Neuarbeitete und erweriterte Auflage, Schulthess Verlag, Zürich, 1988.

ÇABRİ, Sezer, "Karşıl1kl1 Borç yükleyen Sözleşmelerde İfa güçsüzlüğü ve Buna Bağlanan Sonuçlar", Prof. Dr. Mustafa Dural’a Armağan, Filiz Kitabevi, İstanbul, 2013.

ÇETINNER, Bilgehan, "Yeni Türk Borçlar Kanunu'nda Yarar ve Hasarın İntikali ile Satıcının Ayıptan Sorumluluğuna İlişkin Hükümlerin Değerlendirilmesi”, İstanbul Üniversitesi Hukuk Fakültesi Mecmuası, Yı1: 2009, Cilt: 67, Sayı: 1-2, (s. 97-113).

ENGINN, Baki İlkay, Alacağı Temlik Edenin Garanti Sorumluluğu, Seçkin Yayınları, Ankara, 2002.

ENGİN, Baki İlkay, "Alacağın Temliki ve Borcun Nakli”, Türk Borçlar Kanunu Sempozyumu, On İki Levha Yayınları, İstanbul, 2012, (s. 159-168).

ERBAYRAKTAR, BURCU, Alacağın Devrinin Sözleşme ile Engellenmesi (Pactum de non cedendo), On İki Levha Yayıncılık, İstanbul, 2021.

ERCOŞKUN ŞENOL, H. Kübra, Türk Borçlar Kanunu'na Göre Alacağı Devredenin Garanti Sorumluluğu, Adalet Yayınevi, Ankara, 2021.

EREN, Fikret, Borçlar Hukuku Genel Hükümler, 23. Bask1, Yetkin Yayınları, Ankara, 2018. (EREN, 2018, a) 
EREN, Fikret, Borçlar Hukuku Özel Hükümler, 6. Baskı, Yetkin Yayınları, Ankara 2018. (EREN, 2018, b)

FÄSSLER, Benedikt, Der Factoringvertrag im Schweizerischen Recht, Dike Verlag, Zürich, 2010.

FAUST, Florian, BeckOK BGB, Herausgegeben von Wolfgang Hau, Roman Poseck, 57. Edition, C.H. Beck, München, 2021. (https://beck-online.beck.de )

FRANKO, Nisim, “Alacağın Temliki”, Ankara Üniversitesi Siyasal Bilgiler Fakültesi Dergisi, Y11: 1994, Cilt: 49, Sayı: 1, (s. 177-197).

GAUCH, Peter/ SCHLUEP, Walter R., Schweizerisches Obligationenrecht Allgemeiner Teil Band II, 9. Auflafe, ergänzt, verbessert und nachgeführt von Susan Emmenegger, Schluthess, Zürich- Basel-Genf, 2008.

GÜNERGÖK, Özcan, Alacağın Devrinde Borçlunun Hukuksal Durumu, Vedat Kitapçılık, İstanbul, 2014.

HATEMİ, Hüseyin / GÖKYAYLA, Emre, Borçlar Hukuku Genel Hükümler Genel Bölüm, 3. Bası, Vedat Kitapçılık, İstanbul, 2015.

IŞIK, Melih, İcra Hukukunda Borç Ödemeden Aciz Belgesi ve Bu Nitelikteki Haciz Tutanakları (İIK m. 143,105), On İki Levha Yayınları, İstanbul, 2019.

KAHVECI, Nalan, Taşınır Satımında Ayıplı Mal Nedeniyle Tüketicinin Sözleşmeden Dönmesi, Adalet Yayınevi, Ankara, 2014.

KRAUSKOPF, Frédéric, Präjudizienbuch OR, Die Rechtsprechung des Bundesgerichts (1875-2015), Hrsg. Peter Gauch / Viktor Aepli / Hubert Stöckli, 9. Aufl., Zürich - Basel Genf, 2016.

LARDELLI, Flavio, Kurzkommentar OR, Hrsg. Heinrich Honsell, Helbing Lichtenhahn Verlag, Basel, 2014.

NEUMAYR, Mathias, Kurzkommentar Zum ABGB, Hrsg. Helmut Koizol/Raimund Bydlinski/ Raimund Bollenberger, 2. überarbeitete und erweiterte Auflage, Springer WienNew York, 2007. 
OĞUZMAN, Kemal / ÖZ, Turgut, Borçlar Hukuku Genel Hükümler Cilt-2, Gözden Geçirilmiş 14. Bası, Vedat Kitapçılık, İstanbul, 2018.

OZANEMRE YAYLA, Tolunay, Alacağın Devri İşleminin Geçerliliği ve Sebeple Olan İlişsisi (Illîliği), Turhan Kitabevi, Ankara, 2019.

ÖZEN, Burak, 6098 Sayılı Türk Borçlar Kanunu Çerçevesinde Kefalet Sözleşmesi, Vedat Kitapç1lı, İstanbul, 2017.

REETZ, Peter / BURRI, Christof, Obligationenrecht - CHK Handkommentar zum Schweizer Privatrecht Allgemeine Bestimmungen Art. 1-183 OR, Hrsg. Andreas Furrer, Anton K. Schnyder, 3. Auflage, Schulthess Juristische Medien AG, Zürich, 2016.

REISOĞLU, Seza, Garanti Mukavelesi, Ajans-Türk Matbaas1, Ankara, 1963.

RÜZGARESEN, Cumhur, "Mirasbırakanın Borca Batık Olması", Erzincan Binali Yıldırım Üniversitesi Hukuk Fakültesi Dergisi, Y1l: 2010, Cilt: XIV, Say1: 1-2, (s. 271-311).

SEROZAN, Rona, Borçlar Hukuku Özel Bölüm, 2. Bask1, Filiz Kitabevi, İstanbul, 2006.

TANDOĞAN, Haluk, Borçlar Hukuku Özel Borç İlişkileri C. II, Beşinci Tıpkıbasım, Vedat Kitapç1lık, İstanbul, 2010.

TEKİNAY, Selahattin Sulhi / AKMAN, Sermet / BURCUOĞLU, Haluk / ALTOP, Atilla, Tekinay Borçlar Hukuku Genel Hükümler, Yeniden Gözden Geçirilmiş̧ ve Genişletilmiş Yedinci Baskı, Filiz Kitabevi, İstanbul, 1993.

TUNÇOMAĞ, Kenan, Türk Borçlar Hukuku I. Cilt Genel Hükümler, Sermet Matbaası, İstanbul, 1976.

UMAR, Bilge, “Aciz Hali-Borca Batıklık Kavramlarının Farkı ve Bu Yönden Yeni MK Metninin Düştüğü Bir Yanlışlık”, Yeditepe Üniversitesi Hukuk Fakültesi Dergisi, Y1l: 2004, Cilt: I, Say1: 1, (s. 317-324).

UZUN KAZMACI, Özge, Factoring Sözleşmesi, https://tez.yok.gov.tr /UlusalTezMerkezi/tezDetay.jsp?id=ZI7S5G.je_aR_9qSgKlcniA\&no=ZSV8anUW6YUbOe7f_a1_A, (erişim tarihi:11.5.2021). 
ÜÇER, Mehmet, “Roma Hukuku'nda ve Karşılaştırmalı Hukukta Alacağın Temliki”, Ankara Üniversitesi Hukuk Fakültesi Dergisi, Y11: 2005, Cilt: 54, Say1:3, (297-443).

VARDAR HAMAMCIOĞLU, Gülşah, Medeni Hukuk’ta Tasarruf İşlemi Kavramı, On İki Levha Yayınları, İstanbul, 2014.

VON TUHR, Andreas / ESCHER, Arnold, Allgemeiner Teil des Schweizerischen Obligationenrecht, Schluthess Verlag, Zürich, 1974.

WEHRLI, Thomas, Die Vertaglihe Abtretung von Forderungen, Stämfli+Cie AG, Graphisches Unternehmen, Bern, 1993.

İnternet kaynakları:

https://karararama.yargitay.gov.tr. (erişim tarihi: 12.05.2021).

https://tez.yok.gov.tr (erişim tarihi:11.5.2021).

https://www.lexpera.com.tr (erişim tarihi: 20.5.2021)

https://beck-online.beck.de (erişim tarihi: 26.5. 2021) 